\title{
Synthesis of titanium dioxide thin films and its application in reducing microbial load of milk
}

\author{
Shruthi N Kumar ${ }^{\mathrm{a}}$, Manjula Sarode ${ }^{\mathrm{a}}$ and Ravi Shankar H.N. ${ }^{\mathrm{b}}$

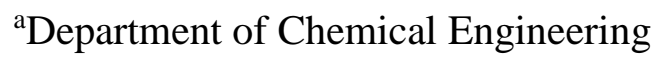 \\ ${ }^{\mathrm{b}}$ Department of Biotechnology
}

R.V. College of Engineering, Bangalore, India

*Correspondence:shruthi.nkumar2@gmail.com, manjulasarode@gmail.com 


\section{Abstract:}

Milk has rich nutritional content packed with fats, proteins and water. It also contains beneficiary and non-beneficiary microbes which account for its short shelf life. Currently cold storage, pasteurization, ultra-high temperature, microfiltration and addition of lactose peroxidase are the methods of choice to control milk spoilage and prolong its shelf life. Their limitations include high energy consumption and loss of variable proportion of heat sensitive nutrients. Titanium dioxide $\left(\mathrm{TiO}_{2}\right)$ nanoparticle coated thin film was used in food packaging industry for its antimicrobial property. $\mathrm{TiO}_{2}$ thin films were synthesized by sol gel process; it was characterized with scanning electron microscopy which showed pore size as $5 \mu \mathrm{m}$ and Fourier transform infrared spectroscopy which showed metal present in sample is $\mathrm{TiO}_{2}$, zinc and silver. Exposure of raw milk at room temperature to $\mathrm{TiO}_{2}$ thin films doped with zinc or copper for a couple of hours showed zone of inhibition in disc diffusion technique, reduction in acid production. It also showed reduction in optical density indicating inhibition of growth in growth curve analysis, increase in the time required for methylene blue reduction and a five log folds decrease in bacterial count estimated using serial dilution plate count. The present studies were carried out under room temperature and pressure which is an added advantage in terms of energy as well as retention of nutrients. Though $\mathrm{TiO}_{2}$ is insoluble in water one needs to address it toxicity issues and adverse effects if any on the nutritional quality of milk before scaling up the process.

\section{Introduction:}

Milk is a rich source of nutrients that helps the growth and maintenance of health of young ones and adults. The National Institute of Nutrition has recommended a minimum of $300 \mathrm{~g}$ daily intake 
of milk for children between 1-3 years of age and $250 \mathrm{~g}$ for those between 10-12 years. It contains $87 \%$ water, $4 \%$ fat and $9 \%$ solid non-fat which include proteins such as casein and albumin, and carbohydrates such as lactose to an extent of $5 \%$ and around $0.7 \%$ ash (Rhea Fernandes, 2009).

Table 1 a: Cow milk composition (Robert G ,1995)

\begin{tabular}{lll}
\hline $\begin{array}{ll}\text { Main } \\
\text { constituent }\end{array}$ & $\begin{array}{l}\text { Range } \\
(\boldsymbol{\%})\end{array}$ & $\begin{array}{l}\text { Mean } \\
(\boldsymbol{\%})\end{array}$ \\
\hline Water & $85.5-89.5$ & 87.0 \\
Total solids & $10.5-14.5$ & 13.0 \\
Fat & $2.5-6.0$ & 4.0 \\
Proteins & $2.9-5.0$ & 3.4 \\
Lactose & $3.6-5.5$ & 4.8 \\
Minerals & $0.6-0.9$ & 0.8 \\
\hline
\end{tabular}

Apart from above mentioned nutrients, milk also consists many micronutrients which are essential for growth of children and adults. Milk contains nine essential nutrients like calcium, protein, vitamin A, vitamin B12, vitamin D, potassium, phosphorus, niacin, riboflavin. Spoilage bacteria may originate on the farm from the environment or milking equipment or in processing plants from equipment, employees, or the air. Microorganism effects quality of milk both physically and chemically in following ways: 


\section{Spoilage type}

Souring

Sweet curdling

Gas production

Ropiness

Red rot

Gray rot

Dairy mould
Microorganisms responsible

Lactobacillus sp. Streptococcus sp.

Bacillus sp.

Proteus sp.

Micrococcus sp.

Clostridium sp. coliform bacteria

Alcaligenes sp.,Klebsiella sp.,Enterobacter sp.

Serratia marcescens

Clostridium sp.

\section{Signs of spoilage}

Sour milk,Curd formation

Alkaline pH

Curd formation

Explosion of curds

Stringy or slimy milk

Red coloration

Gray coloration, Foul smell

Penicilium sp.,Geotrichum sp. Mouldy appearance

Table 1b: Spoilage of microorganisms. 


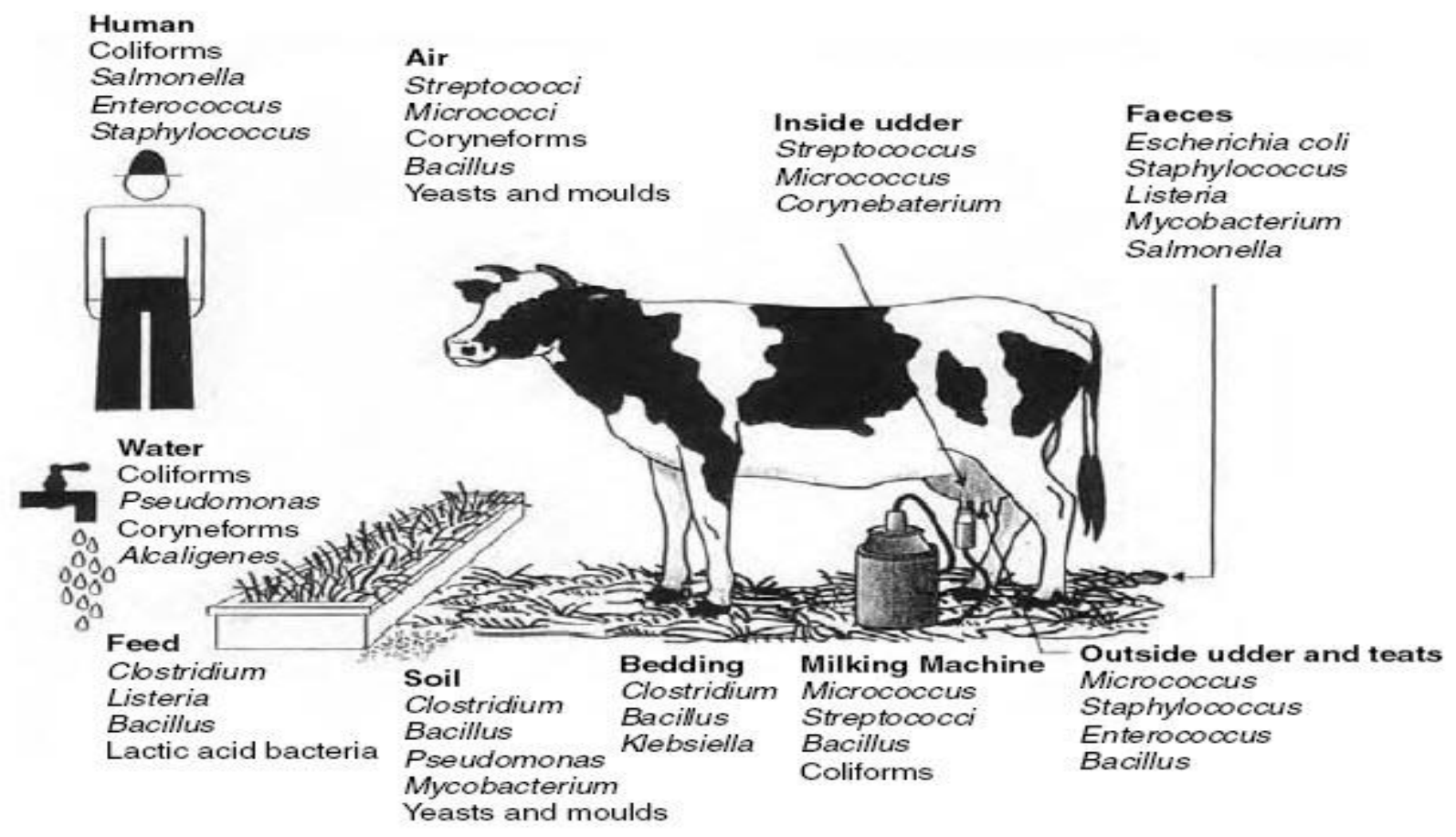

Fig 1: Sources of microbial contamination in milk (Loralyn H. Ledenbach and Robert T. Marshall, 2009)

\subsection{Indian dairy industry}

India is leading milk producer in the world and has about $15 \%$ of world's livestock population.

Milk production in India is greater than 16\% (135 MT) of world's production. 


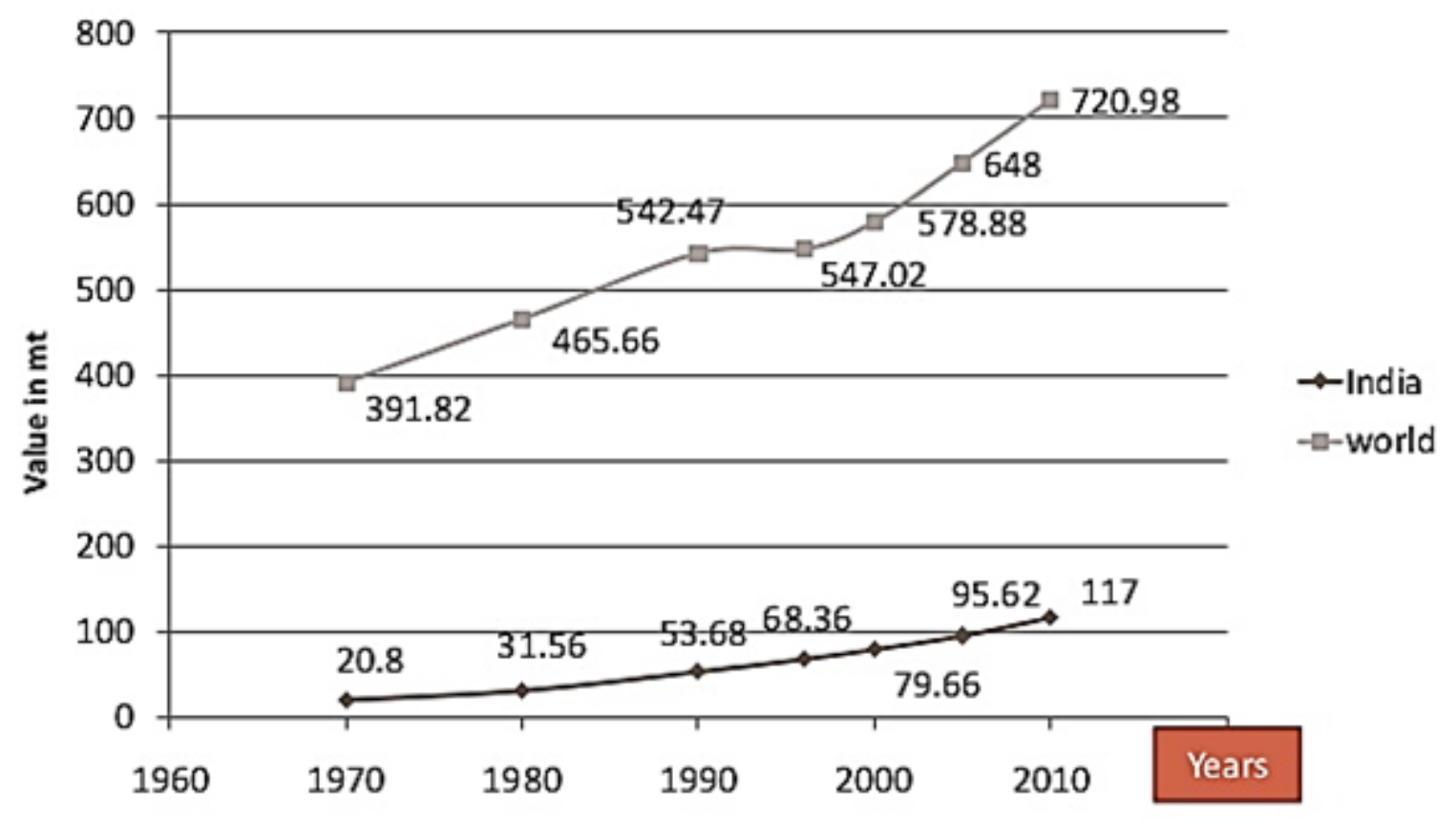

Fig 1.1a Trend in milk production world-India (Source-NDDB)

Indian dairy sector contributes majority share in domestic products. Presently India has about 69,000 dairy cooperatives which gives employment to more than $72 \mathrm{mn}$ dairy farmers. Despite the increase in milk production in last three decades (reference: Operation Flood), milk yield per animal is still low. The main reasons for the low yield are lack of use of modern practices in milking, fodder in all the seasons, access to veterinary health services. Indian dairy has improved over years from importer to exporter that is per capita availability from $132 \mathrm{~g} /$ day to $302 \mathrm{~g} /$ day. Milk undergoes various processes before reaching the consumer and also there is a huge loss of produced milk (4). 


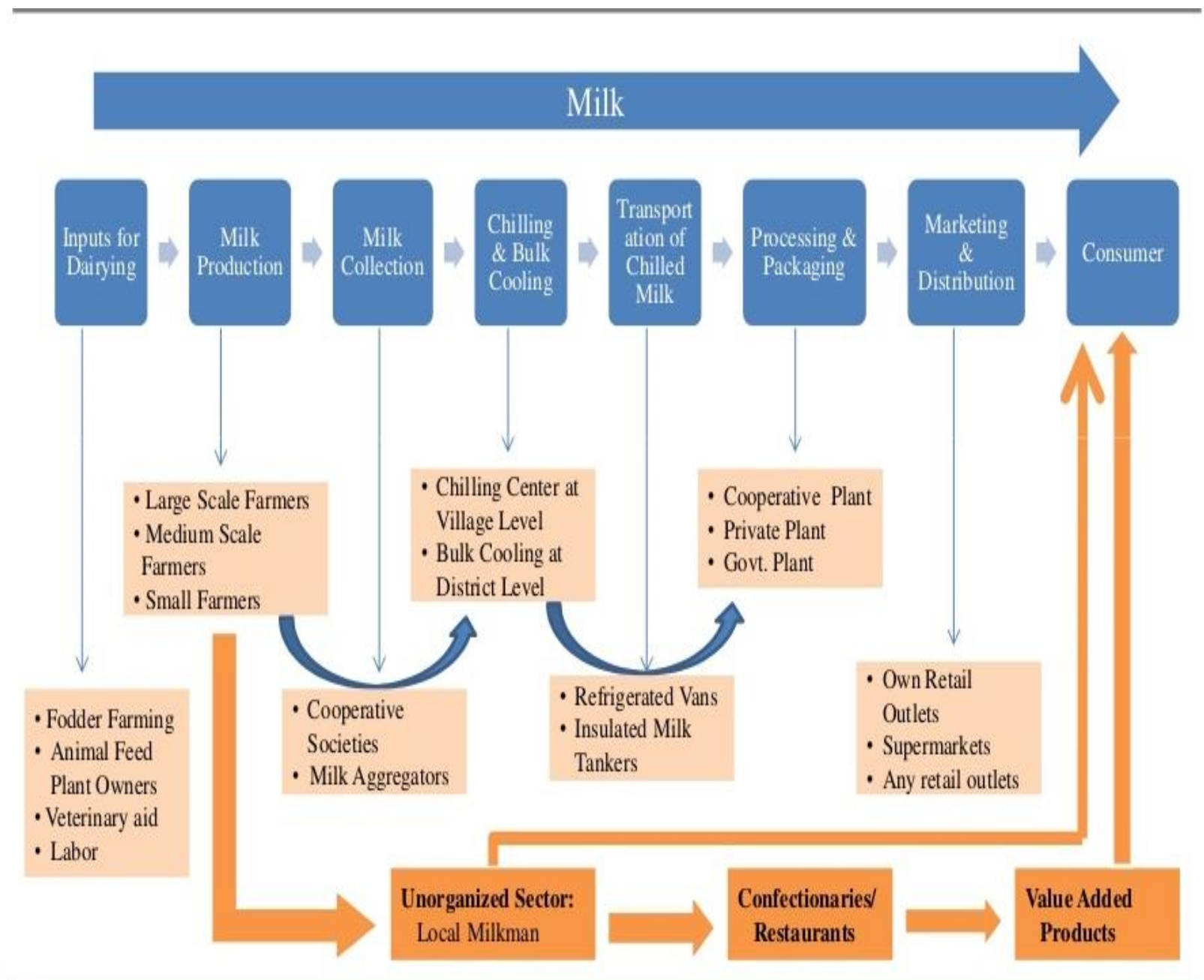

Figure 1.1b : Supply chain in Indian dairy industry.

Table 1.1: Main problems in Indian dairy industry is at various levels:

Small holder level
At this level there is lack of good quality feed, veterniary facilities, chilling facilties. 


\begin{tabular}{|c|c|}
\hline Collection level & $\begin{array}{l}\text { Here there is lack of infrastucture and also } \\
\text { there are too many itermediates. Also there is } \\
\text { manipulation of quality of milk by farmers }\end{array}$ \\
\hline Processing level & $\begin{array}{l}\text { Here there is seasonality of production and } \\
\text { fluctuating supply, absence of quality } \\
\text { standards, adulteration is more and lack of } \\
\text { trained and skilled workers. }\end{array}$ \\
\hline Storage and logistics level & $\begin{array}{l}\text { Here lack of cold storage facilities and also gap } \\
\text { in cold chain and transport facilities. }\end{array}$ \\
\hline Co-operative level & $\begin{array}{l}\text { Ther is lesser participation in the decision } \\
\text { making process, inefficient services and lastly } \\
\text { insufficient infrastructure. }\end{array}$ \\
\hline Marketting level & $\begin{array}{l}\text { There is lack of transparent milk pricing } \\
\text { system. }\end{array}$ \\
\hline
\end{tabular}

\subsection{Milk processing}

Milk is collected from farms and stored under chilled conditions at around $4{ }^{\circ} \mathrm{C}$, where mostly Pseudomonas species like P.fluorescens, P.fragi, P.lundensis survive and also stable proteolytic and lipolytic enzyme survive even in Ultra-High Temperature (UHT) which cause further spoilage. 
To control psychotrophs, normally industries follow various steps like thermisation where milk is heated to $57-68^{\circ} \mathrm{C}$ for $15-20 \mathrm{~s}$ followed by rapid cooling at $<6^{\circ} \mathrm{C}$. This eliminates lot of psychotrophic bacteria but not vegetative pathogens, for example Listeria monocytogenes which survive under UHT conditions and grow under chilled conditions (Mackey B.M., \& Bratchell N. 1989; Bradshaw et.al,1991; Knabel et.al, 1991; Farber et.al,1992; Linton et.al, 1990). Deep cooling is the process where milk is stored at temperature as low as $4^{\circ} \mathrm{C}$ to improve the shelf life of milk. In carbon dioxide addition method, carbon dioxide is added at concentration of 20-30 mM (Amigo L \& Calvo M.M.,1996; Joseph et.al 2006) which inhibits microbes by lowering pH or displacing oxygen or inhibiting production of enzymes but major concerns were these help in growth of Clostridium botulinium (Glass et.al, 1999).

Other methods that are more commonly used to increase the shelf life of milk are pasteurisation and UHT. In pasteurization, milk is heated either at low temperature for long time (LSLT, $63-65^{\circ} \mathrm{C}$ for $30 \mathrm{~min}$ ) or high temperature for short time (HTST, $71-72^{\circ} \mathrm{C}$ for $15 \mathrm{~s}$ ) where majority of pathogens are killed but not spores and in case of UHT, milk is heated to $120{ }^{\circ} \mathrm{C}$ for 30 min where majority of spores are destroyed.

Apart from above practised methods newer methods to increase shelf life of milk are being experimented like silver nanorods (Padmanaban et.al, 2013) have been used in dairy industry with promising results, use of casein micelles as nutraceuticals (Semo et.al, 2007), alpha lactalbumin nanotube (J.F. Graveland-Bikker, C.G. de Kruif, 2006) and $\mathrm{TiO}_{2}$ thin films for food packaging (Siti et.al 2014) are recent advances.

In case of India, alternative methods need to be thought of apart from conventional methods for chilling. Major reasons being chilling requires lot of energy and uniterrupted power 
supply. Next being cows are milked twice a day except 15 days before calf is born and 5 days after its birth and milk needs to be chilled within $4 \mathrm{~h}$ of drawing since India being tropical country, chances of spoilage is relatively higher. Others reasons for the need of alternative method is distance between village and processing unit is quiet far. So alternative was Rapid Milk Chiller, thermal battery operated chiller which is efficient if produce is about 5001 .

\section{$1.3 \mathrm{TiO}_{2}$ thin films}

Silver is antimicrobial and has various application but it is expensive, so cheaper alternatives were sought. $\mathrm{TiO}_{2}$ has properties of being antimicrobial, stable, cheaper, hydrophilic, non-toxic etc. makes it an alternative choice for silver. $\mathrm{TiO}_{2}$ exists in three phases; brookite (orthorhombic), anatase (tetragonal) and rutile (tetragonal) A wide range of techniques have been used for synthesis of thin films such as Hydrothermal methods, Electron beam evaporation , magnetron sputtering, solvo thermal synthesis and sol-gel methods.Among these techniques the sol-gel method offers several advantages like homogeneous films, simpler processing, variation of thickness and area of the films (Chopra, 1986; West, 2003).

\subsection{Antimicrobial activity of $\mathrm{TiO}_{2}$}

$\mathrm{TiO}_{2}$ was used in air, water and surface disinfection, and also in inhibition of foodborne microorganisms. The microorganisms include foodborne microorganisms such as E.coli, Bacillus cereus, Staphylococcus aureus, Norovirus and several salmonella strains etc. 


\section{Gram Positive}

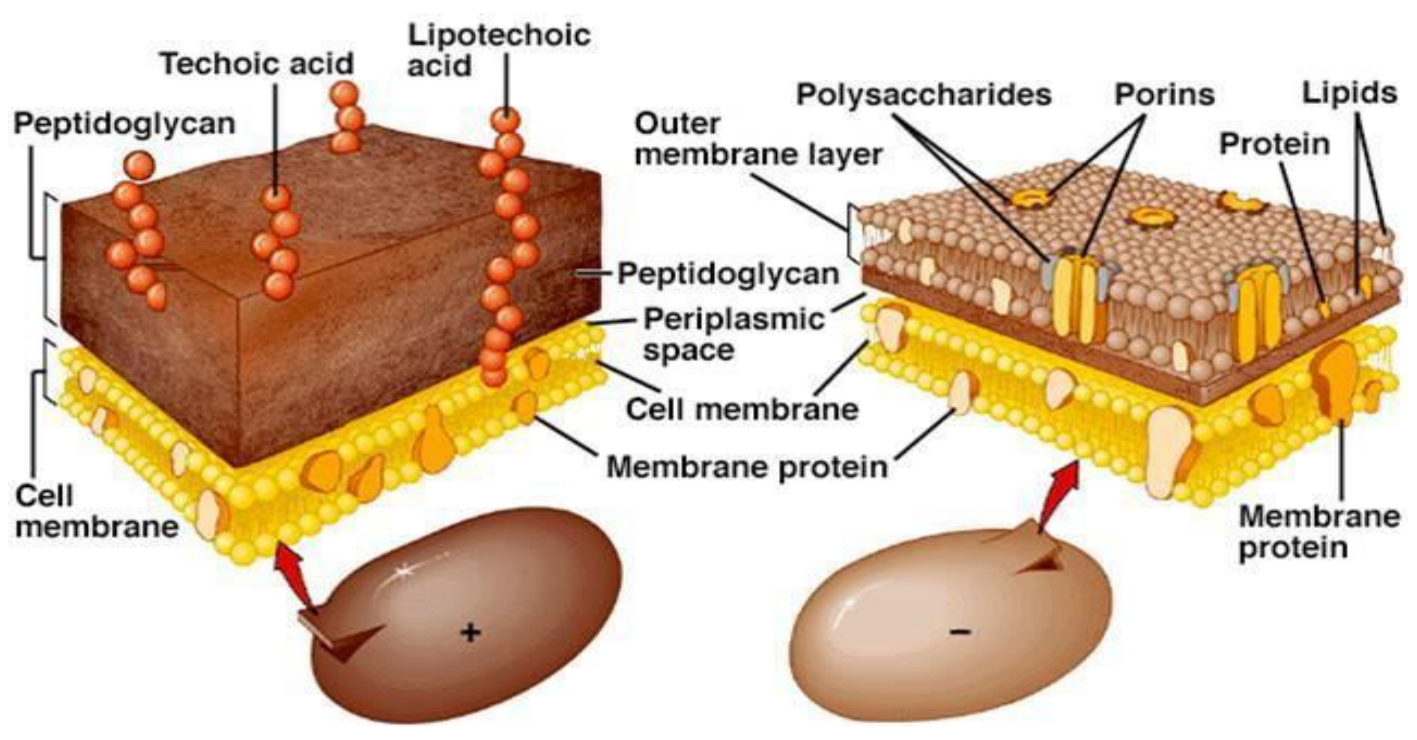

Fig 1.4 a - Cell wall constitution in gram-positive (left) and gram-negative (right) bacteria (adapted [21]).

Gram-positive bacteria cell wall possesses a thick peptidoglycan layer (PG) and an inner membrane (cytoplasmic membrane or inner membrane, IM), while gram- negative cell wall is made of an outer membrane (OM), a thin PG layer and an IM. The differences in cell wall composition is reason for resistance to disinfection of gram-positive bacteria compared to gramnegative.

Another study of photokilling process of E.coli by using AFM showed disordering of the OM of bacteria cells by reactive species $\left(\bullet \mathrm{OH}, \mathrm{H}_{2} \mathrm{O}_{2}, \mathrm{O}_{2} \bullet-\right)$ (Figure 2.5 (ii)), which leads to changes in the permeability of ROS and, as a result, enable an easy attack to the inner membrane, resulting in the peroxidation of the lipids that constitute the cytoplasmic membrane. The destabilization of the cytoplasmic membrane leads to changes in the cell permeability, with the loss of ions (disruption 
of the electrochemical balance) and other important molecules, eventually resulting in loss of cell viability and ultimately cell death (Sunada et.al,2003).

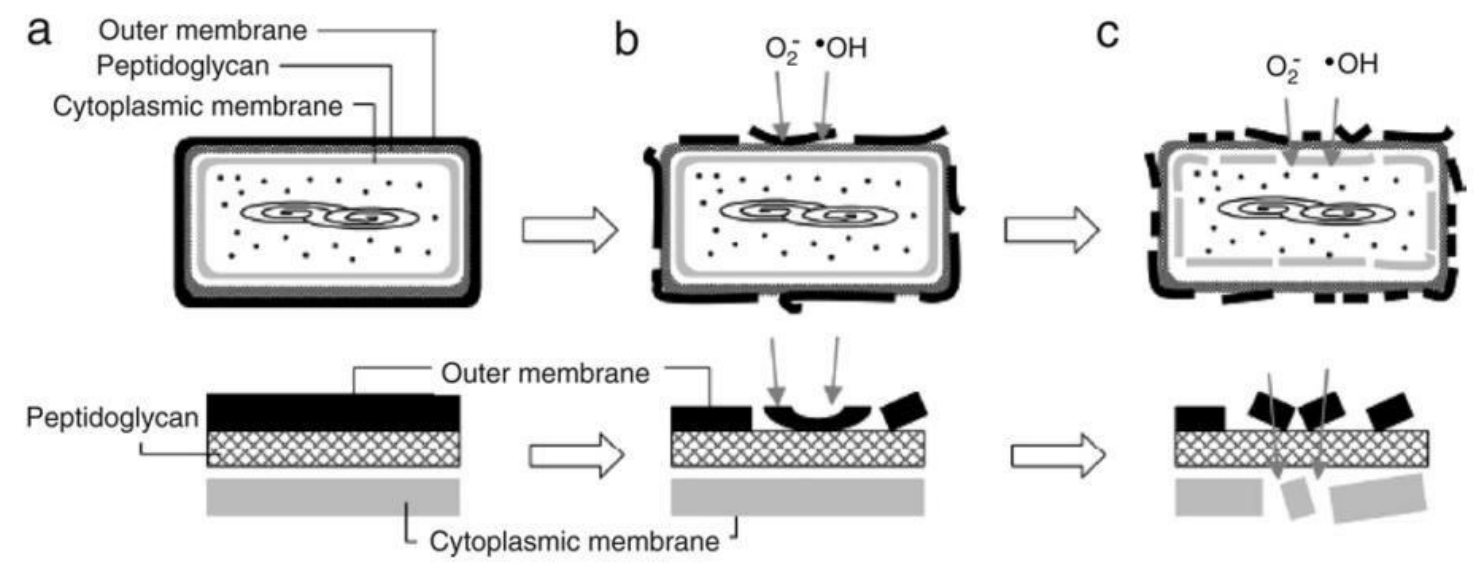

Fig $1.4 \mathrm{~b}$ - Schematic illustration of the stages in the process of E. coli photokilling on a TiO2 film. In the lower row, part of the cell envelope is magnified (adapted [21])

\subsection{Toxicology of $\mathrm{TiO}_{2}$}

$\mathrm{TiO}_{2}$ is generally insoluble in water but $\mathrm{TiO}_{2}$ nanoparticles are expected to alter biological properties like bioavailability and cytotoxicity. Apart from National Institute for Occupational Safety and Health (NIOSH) recommended exposure limits (REL) no other exposure limits have been set and tolerance limits is $5-10 \mu \mathrm{g} / \mathrm{ml}$. In certain invitro and invivo experiments, reproductive and developmental toxicity is studied but results are unclear. Accumulation of $\mathrm{TiO}_{2}$ in organs and tissues may take place on continuous exposure and also this may cause generation of reactive 
oxygen species (ROS) and alternate cell signal in pathways that play role in understanding behaviour of carcinogenesis. It also has shown to cross blood-brain, blood-placenta barriers. Toxicokinectic studies include absorption, distribution, excretion, accumulation and metabolism through different route in body. Further studies need to focus on systemic response from organ exposure and biomarker reflecting exposure and toxic effect (Hongbo Shi et.al,2013; Jinyuan Chen et.al,2009).

In the present work, $\mathrm{TiO}_{2}$ thin films were synthesised using sol gel process and doped with metals like zinc, copper. The synthesized films were used to study their effect on reducing microbial load of water and the studies were extended on milk samples.

\section{Materials}

Fresh cow milk was collected under hygienic conditions in clean vessels from a nearby farm and brought to the laboratory under cold conditions. Cow milk was allowed to rest under chilled conditions $\left(4^{\circ} \mathrm{C}\right)$ for four hours before conducting the experiments in order to settle the gas produced during milking. Zinc nitrate, cuprous chloride, titanium isopropoxide, acetyl acetone, CTAB, silver nitrate, isopropyl alcohol, vanadium pentoxide, iodine, potassium iodide, potassium chromate, zinc chloride were of analytical grade and were obtained from Industrial labs, Bangalore. Nutrient broth, agar agar, methylene blue powder, phenolphthalein indicator, resorcinol was procured from Merck chemicals, Bangalore.

\section{Methodology:}

\subsection{Preparation of thin films:}

Titanium dioxide thin films was prepared using titanium isopropoxide solution and isopropanol in volume ratio of 1:5 in a beaker and the mixture was stirred for 10 minutes till yellow colour solution was obtained. Later $5 \mathrm{ml}$ of acetyl acetone solution was added to the above solution 
followed by addition of CTAB solution $(0.03 \%)$ and the contents were stirred till clear solution was obtained (Isrihetty Senain et.al,2010).

\subsection{Doping of $\mathrm{TiO}_{2}$ thin films:}

\subsubsection{Selection of dopants}

Dopants were selected on basis of solubility in isopropanol solution and also their stability (24 hrs)(Ravishankar Rai V and Jamuna Bai A ,2011).

\begin{tabular}{|l|l|}
\hline Dopants & Result (solubility and stability) \\
\hline Iron (Ferrous sulphate) & Negative (soluble, not stable) \\
\hline Zinc (zinc nitrate) & Positive (soluble, stable) \\
\hline Copper (cuprous sulphate) & Negative (partially soluble, not stable) \\
\hline Nickel (nickel chloride) & Negative (not soluble, not stable) \\
\hline Copper (cupric chloride) & Positive (soluble, stable) \\
\hline Manganese (Manganese sulphate) & Negative (soluble, not stable) \\
\hline Magnesium (Magnesium chloride) & Negative (not soluble, not stable) \\
\hline Cobalt (cobalt oxide) & Negative (not soluble, not stable) \\
\hline
\end{tabular}

Based on above criteria copper and zinc were chosen.

Metal dopants zinc and copper was added to thin films prepared in section 3.1 and the solution was used in synthesizing the films by coating on a microslide using spin coating apparatus (DELTA SPIN-1 RC2100XT543) at $300 \mathrm{rpm}$ initially for few seconds, which was increased to $1000 \mathrm{rpm}$ for $5 \mathrm{~min}$. Then these films were dried in hot air oven at $60^{\circ} \mathrm{C}$ for $30 \mathrm{~min}$ and annealed at $200^{\circ} \mathrm{C}$ for $1 \mathrm{~h}$ in muffle furnace.

\subsection{Testing for microbial and keeping quality of milk:}




\subsubsection{Disc diffusion test:}

Nutrient Agar was prepared using $2.72 \mathrm{~g}$ dehydrated nutrient broth powder in $200 \mathrm{ml}$ of water mixed with $4 \mathrm{~g}$ (2\%) of agar in $250 \mathrm{ml}$ conical flask and autoclaved at $121^{\circ} \mathrm{C}, 15$ PSI pressure for $15 \mathrm{~min}$ and on cooling was poured into sterile petri plates. E.coli culture suspension was spread on the surface of agar to develop a lawn of bacteria. Sterile Filter paper discs were loaded with 20 $\mu 1$ of test solution and placed on agar surface under aseptic conditions. Standard antibiotic disc was included as a positive control. The plates were incubated at $30^{\circ} \mathrm{C}$ for $48 \mathrm{~h}$ and observed for the presence of zone of inhibition.

\subsubsection{Growth curve analysis}

Nutrient broth was prepared as in section 3.3.1 and was inoculated heavily with E.coli culture in $250 \mathrm{ml}$ conical flask. The inoculum was incubated in an orbit shaker at $100 \mathrm{rpm}$ at $30^{\circ} \mathrm{C}$ in presence or absence of titanium isopropoxide with and without dopants. The absorbance at $600 \mathrm{~nm}$ was read every $1 \mathrm{~h}$ in photoelectric colorimeter (Model: SYNTRONICS 112) with respect to control, blank and test compounds.

\subsubsection{Methylene blue reduction test:}

One $\mathrm{ml}$ of $1 \%$ methylene blue solution was added to $9 \mathrm{ml}$ of water or milk to be tested in presence or absence of test compounds and the time taken for the disappearance of blue colour was recorded.

\subsubsection{Serial dilution Plate count:}

One $\mathrm{ml}$ of the sample to be counted is added to $9 \mathrm{ml}$ of sterile $0.85 \%$ saline solution, which is vortexed and serially diluted in saline. An aliquot was spread in duplicate on nutrient agar plates and incubated at $30^{\circ} \mathrm{C}$ for $48 \mathrm{~h}$. The number of bacterial colonies that developed were counted and used to calculate the bacterial numbers per ml of test sample. 


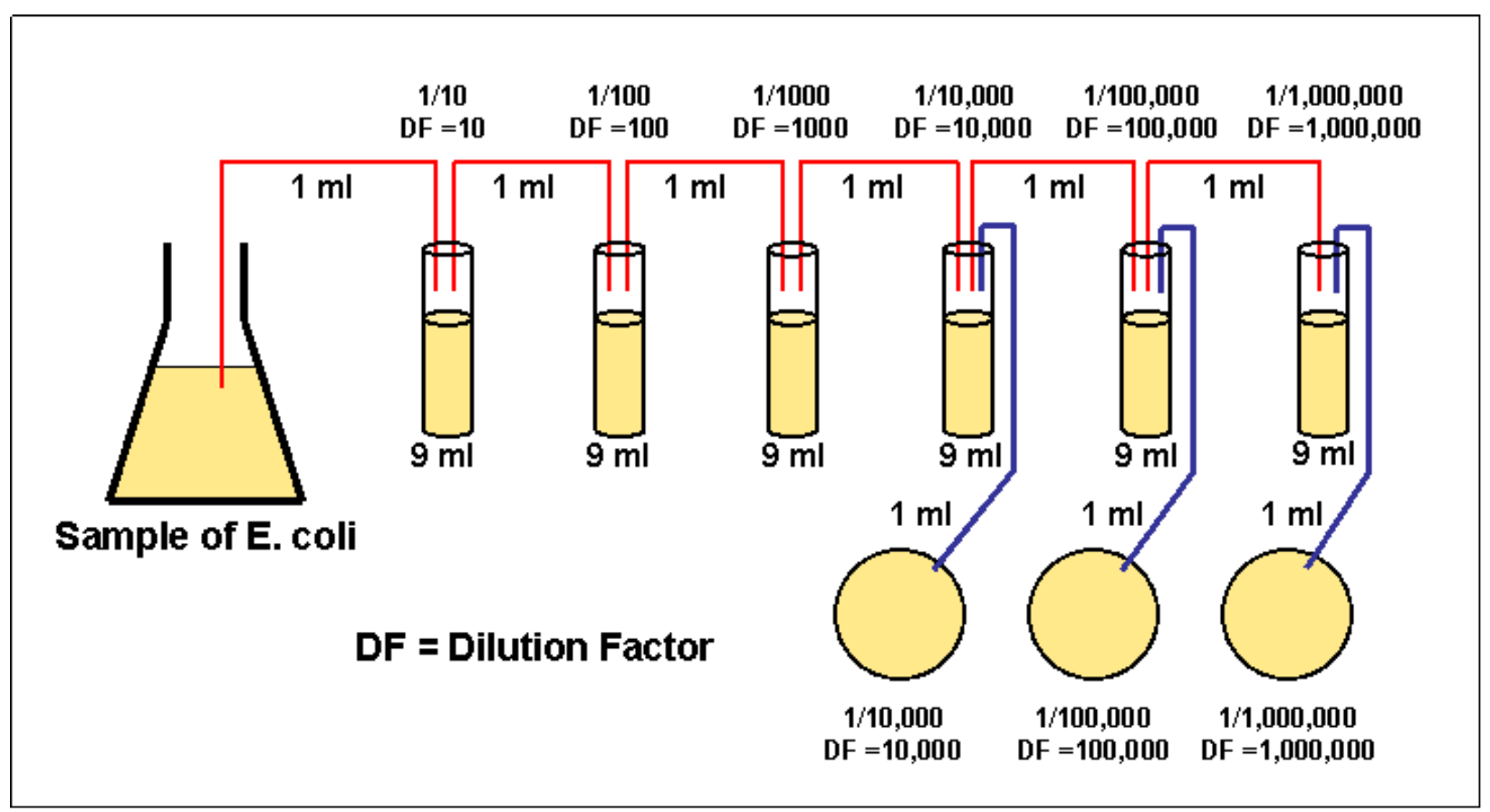

Fig 3.3.4 Serial dilution method

\subsubsection{Clot on boiling:}

Milk sample was taken in test tube and heated over flame in laminar airflow (LAF) to check whether milk curdles or not.

\subsubsection{Titrable acidity:}

An aliquot of milk sample was titrated against $0.01 \mathrm{~N} \mathrm{NaOH}$ with 2 drops of phenolphthalein as indicator and amount of $\mathrm{NaOH}$ consumed before the solution turned pink was noted and was calculated as:

Titrable acidity $=$ Normality $\times 9 \times$ titrable value $/$ volume ofmilk

\subsubsection{Quality Analysis of Raw Milk Sample}

a) Detection of Cane Sugar by using Modified Seliwanoff's method: $0.5 \mathrm{~g}$ of resorcinol was dissolved in $40 \mathrm{ml}$ of distilled water. To this $35 \mathrm{ml}$ of conc $\mathrm{HCl}$ was added and make up volume to $100 \mathrm{ml}$ using distilled water. $1 \mathrm{ml}$ of milk and $1 \mathrm{ml}$ of resorcinol solution was 
taken in test tube and placed in boiling water bath for 5 minutes and change in colour (either cherry red or pink) was observed.

b) Test for presence of Hydrogen Peroxide: $1 \mathrm{~g}$ of vanadium pentoxide was dissolved in 100 $\mathrm{ml}$ dilute sulphuric acid (6 $\mathrm{ml}$ concentrated sulphuric acid was diluted to $100 \mathrm{ml}$ ). 10-20 drops of reagent were added to $10 \mathrm{ml}$ milk sample and mixed and colour change was observed that is red or pink.

c) Detection of Cellulose in Milk: Iodine-zinc chloride reagent was prepared by dissolving 10 $\mathrm{g}$ of zinc chloride in $4.25 \mathrm{ml}$ water and after cooling iodine solution was added drop wise till it precipitates out. Iodine solution was prepared by mixing $1.5 \mathrm{~g}$ potassium iodide with $0.75 \mathrm{~g}$ of iodine in $30 \mathrm{ml}$ water. $10 \mathrm{ml}$ of milk was taken in a $100 \mathrm{ml}$ beaker. To this $50 \mathrm{ml}$ of hot water was added and stirred thoroughly for about 2 min until it dissolved. The mixture was filtered with filter paper twice using hot water. Residue was scraped and placed on a glass slab and colour change was observed that is blue colour in iodine-zinc chloride region and no blue colour in iodine region.

d) Detection of Sodium Chloride in milk: $5 \mathrm{ml}$ of milk sample was taken in a beaker and $1 \mathrm{ml}$ of $0.1 \mathrm{~N}$ silver nitrate solution was added to it. The contents were mixed thoroughly and $0.5 \mathrm{ml}$ of $10 \%$ potassium chromate solution was added to it. The colour of resulting solution was observed; appearance of yellow coloured solution will indicate presence of chlorine.

e) Detection of Starch: Iodine solution was prepared by dissolving $1.3 \mathrm{~g}$ of iodine and $1.5 \mathrm{~g}$ of potassium iodide and volume was made up to $100 \mathrm{ml}$ using distilled water. About $5 \mathrm{ml}$ of milk sample was taken in a test tube. Milk was boiled and test tube was allowed to cool to room temperature. 1-2 drops of iodine solution were added to the test tube. Development of blue colour, which disappears when sample is boiled and reappears on cooling, indicates presence of starch.

f) Total Solid Fat content: The weight of empty crucible was noted. $5 \mathrm{ml}$ of milk sample was taken in it and weighed (W1). It was placed in hot air oven at $110^{\circ} \mathrm{C}$. After one hour the sample was taken out and weighed again (W2). Total solids were determined as a percentage of the difference between these two weights.

g) Specific Gravity of samples: The raw milk sample was filled in a specific gravity bottle. The weight of the bottle with and without sample was noted. 
h) $\mathrm{pH}$ of samples: The sample was poured into a sterile beaker and placed in a water bath at room temperature, its $\mathrm{pH}$ was measured using $\mathrm{pH}$ meter.

\section{RESULTS}

\subsection{Characterisation results:}

Thin films of $\mathrm{TiO}_{2}$ doped with zinc and copper were prepared as described in methods section 3.1 and 3.2 and characterized using FTIR and SEM techniques.

4.1.1 FTIR: Fig 4.1.1 shows the Infra red spectral scan of $\mathrm{TiO}_{2}$ doped with zinc. Two peaks were observed at 700 and $1000 \mathrm{~cm}^{-1}$. This means it contains functional groups of $\mathrm{OH}$ and $\mathrm{CH}_{3} \mathrm{obtained}$ from isopropanol. Figure 4.1.2 shows the spectral scan of $\mathrm{TiO}_{2}$ doped with zinc and silver. Peak broadening may be observed at 1000 to $1220 \mathrm{~cm}^{-1}$. This is possibly due to presence of zinc.

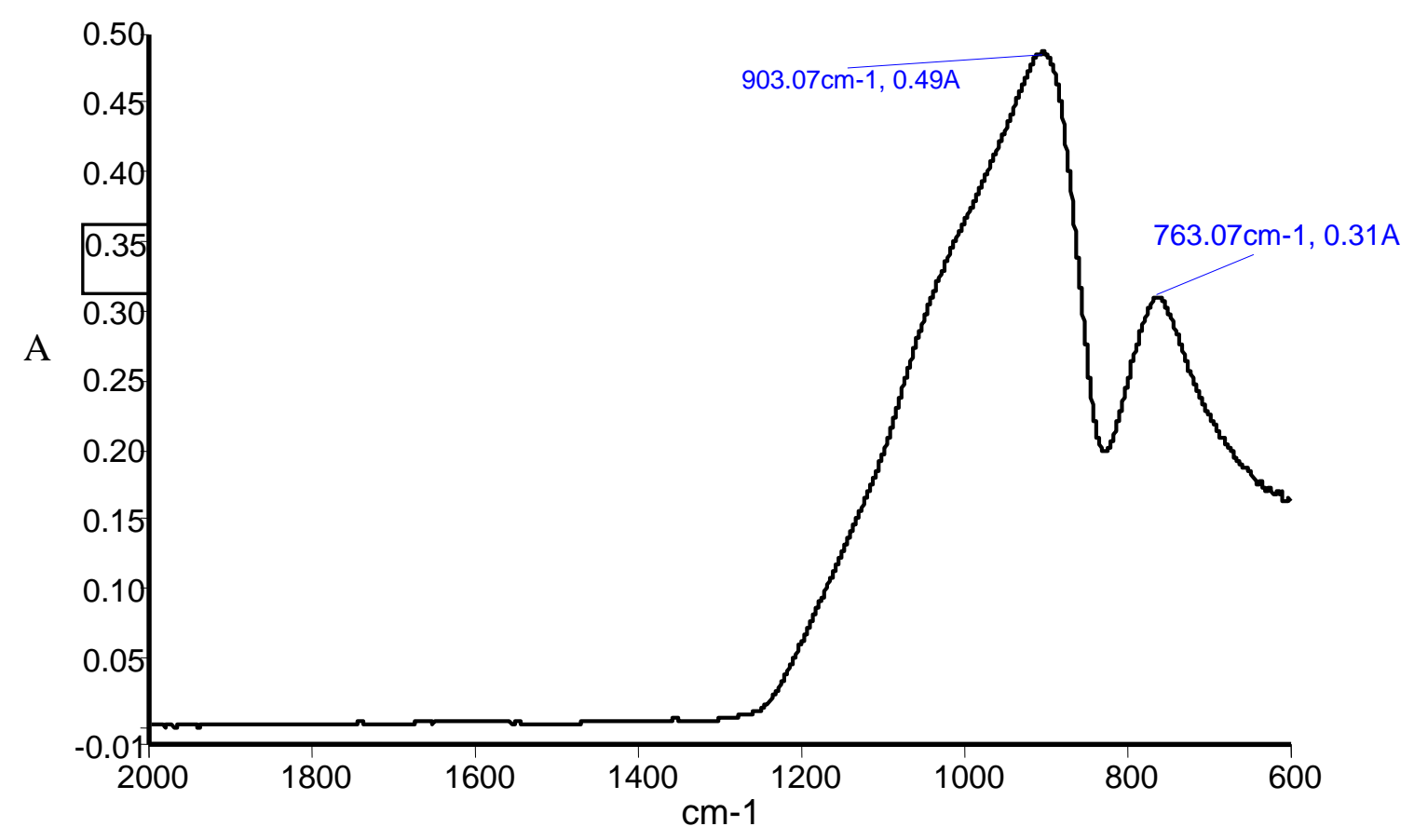


*A-absorbance, $\mathrm{cm}^{-1}$-wavelength

Fig 4.1.1a: FTIR spectral scan of $\mathrm{TiO}_{2}$ doped with zinc

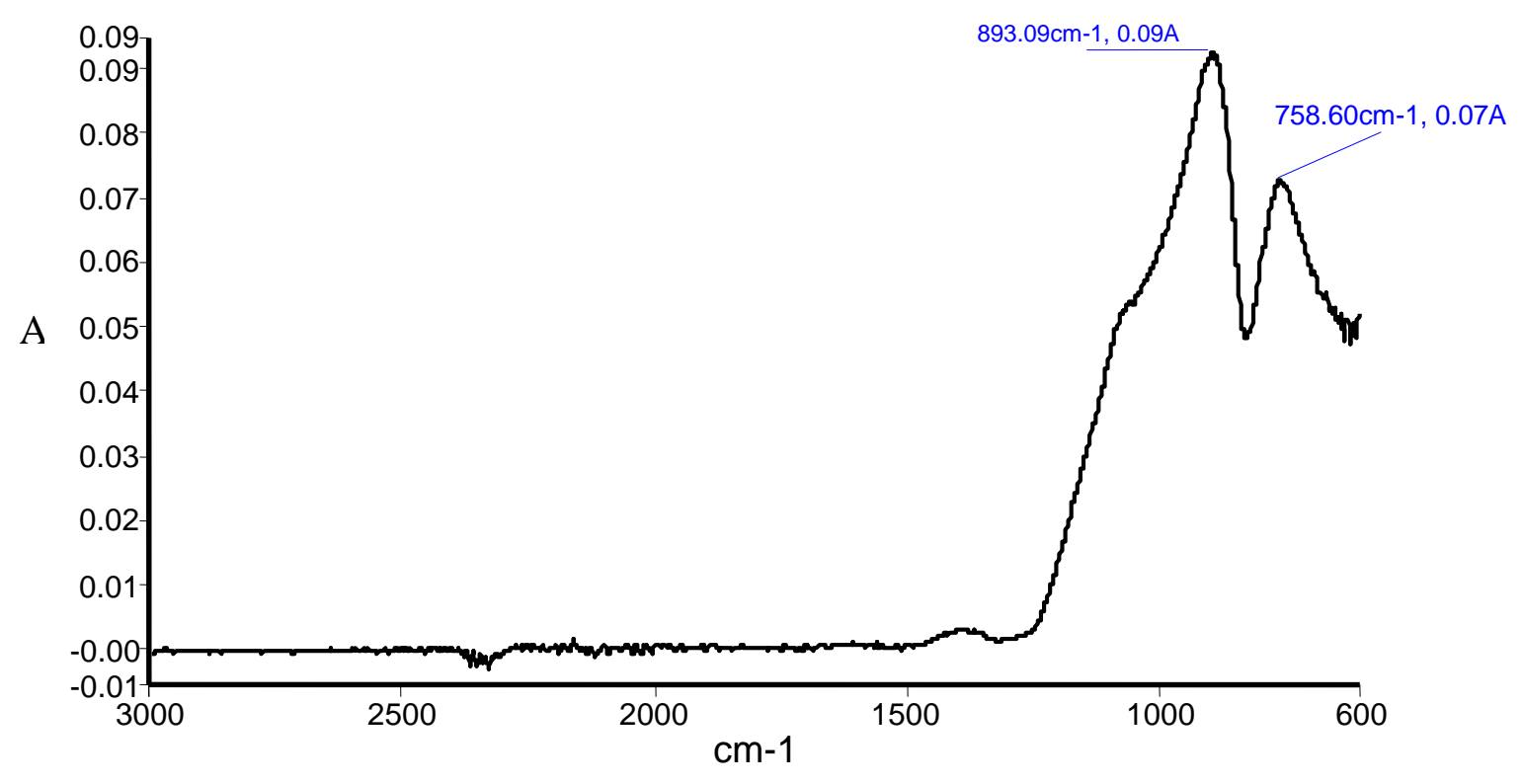

*A-absorbance, $\mathrm{cm}^{-1}$-wavelength

Fig 4.1.1b: FTIR spectral scan of $\mathrm{TiO}_{2}$ doped with zinc and silver

These tests show the presence of $\mathrm{TiO}_{2}, \mathrm{Zn}, \mathrm{Ag}$. 


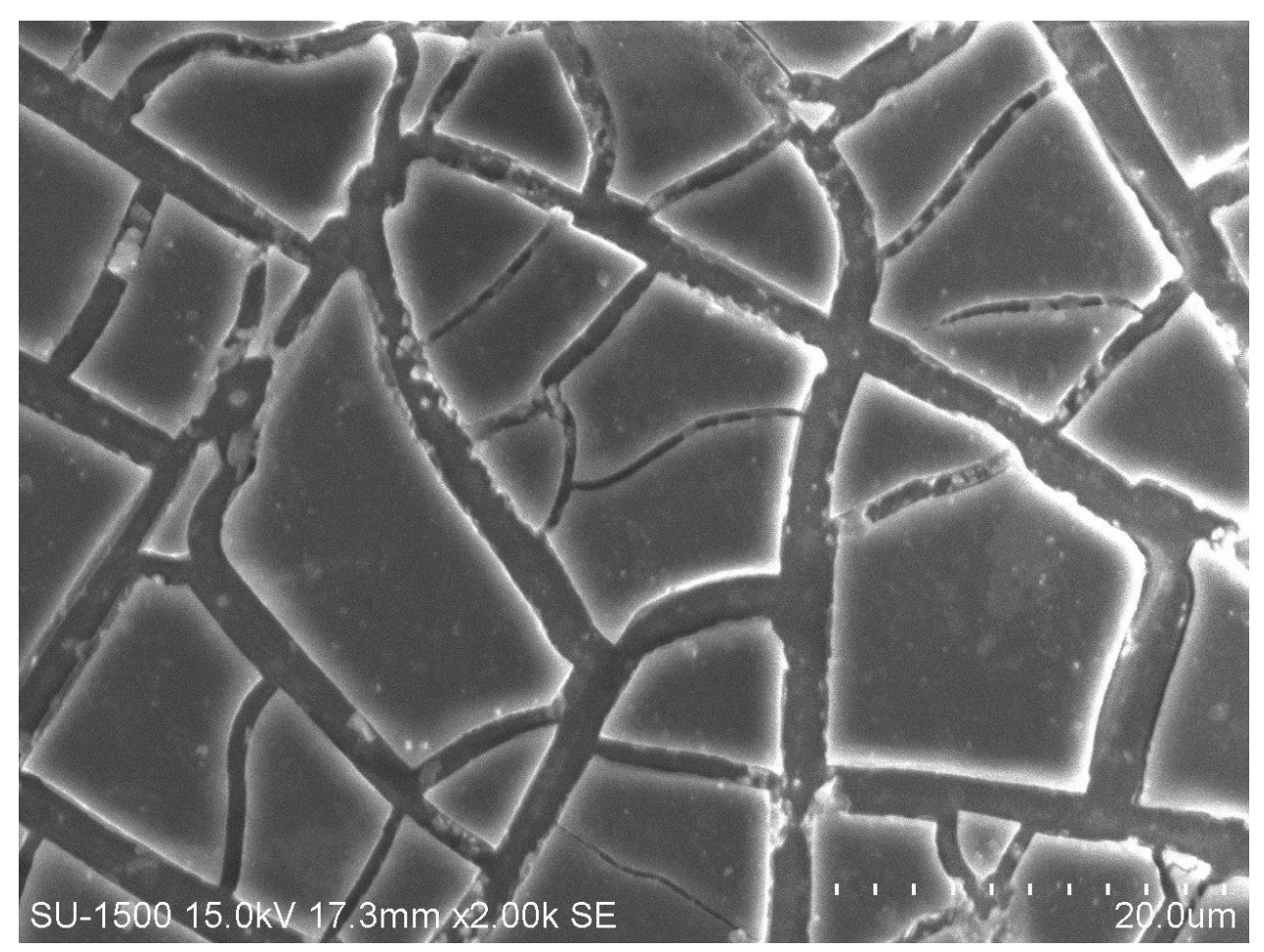

Fig 4.1.2: SEM image of $\mathrm{TiO}_{2}$ doped with zinc and silver.

4.1.2 SEM: SEM image is taken at magnification of 500x resolution and it was also observed that there is lot of crack on thin film which could be due to lot of heat generated on impact of electrons with the sample. Size of microbes normally varies from $0.5 \mu \mathrm{m}$ to $2 \mu \mathrm{m}$ whereas approximate pore size analysed based on SEM image is $0.5 \mu \mathrm{m}$

\subsection{Effect of exposure $\mathrm{TiO}_{2}$ thin films on microbial load of water:}

Drinking water is normally clear and free of contamination but in some cases it can also contain heavy metals, microbes, etc. As water acts as carrier media for microbes, the effect of the synthesized thin films on water was studied to reduce the microbial load reduction.

The change in microbial load of water samples after its exposure to $\mathrm{TiO} 2$ thin films was assessed by disc diffusion test, growth curve analysis, methylene blue reduction test and serial dilution plate count.

\section{DISC DIFFUSION TEST}


E.coli was used as a test organism, to study the effect of various concentrations of zinc and copper as dopants in titanium isopropoxide solution which was tested by disc diffusion test. When sterile filter paper disc impregnated with a known concentration of test solution is placed on agar plate, immediately water is absorbed into the disc from the agar.

The result of disc diffusion test is shown below. It appears that titanium isopropoxide by itself inhibits the growth of E.coli and addition of zinc and copper at 2\%,4\%,6\%,8\% and 10\% improve the degree of inhibition since there was increase in the diameter of zone of inhibition.

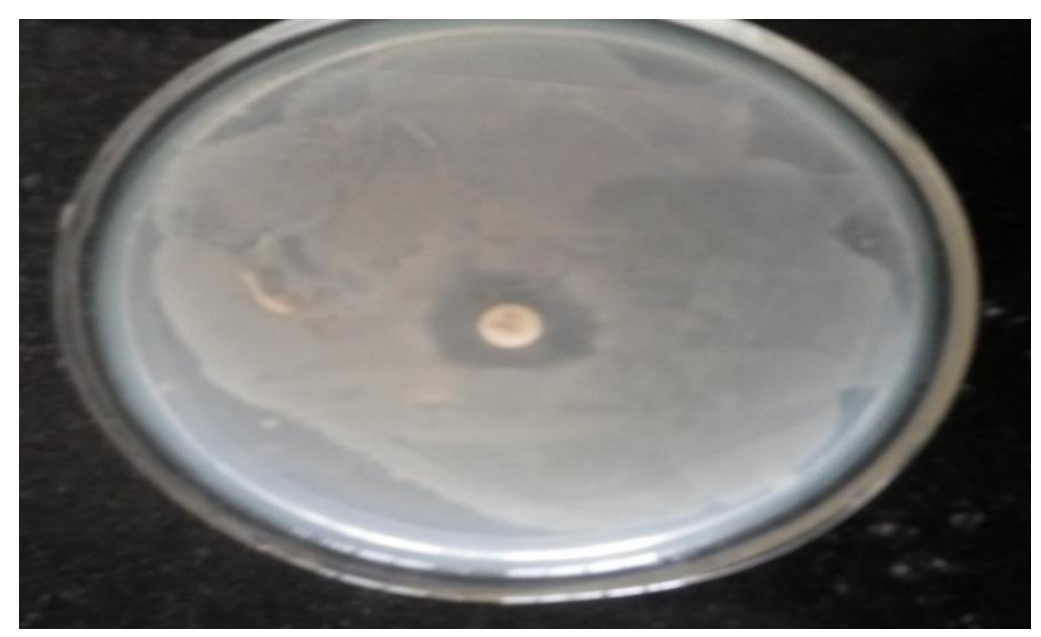

Fig 4.2.1a: Standard disc (Ampicillin $10 \mathrm{mg}$ as positive control). 


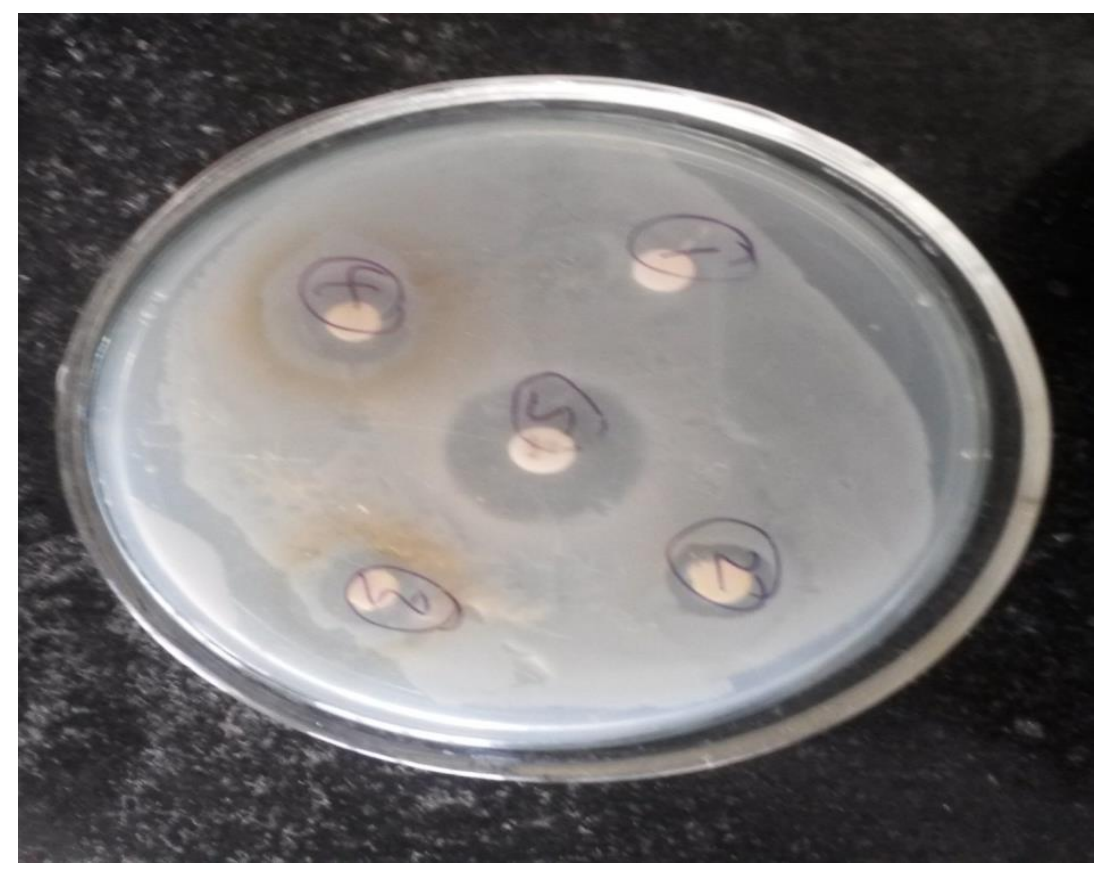

Fig 4.2.1b: Treatment 1: Isopropanol ; Treatment 2:0.02g of copper/ml of titanium isopropoxide; Treatment 3:0.04g of copper/ml of titanium isopropoxide; Treatment 4:0.06g of copper/ml of titanium isopropoxide; standard.

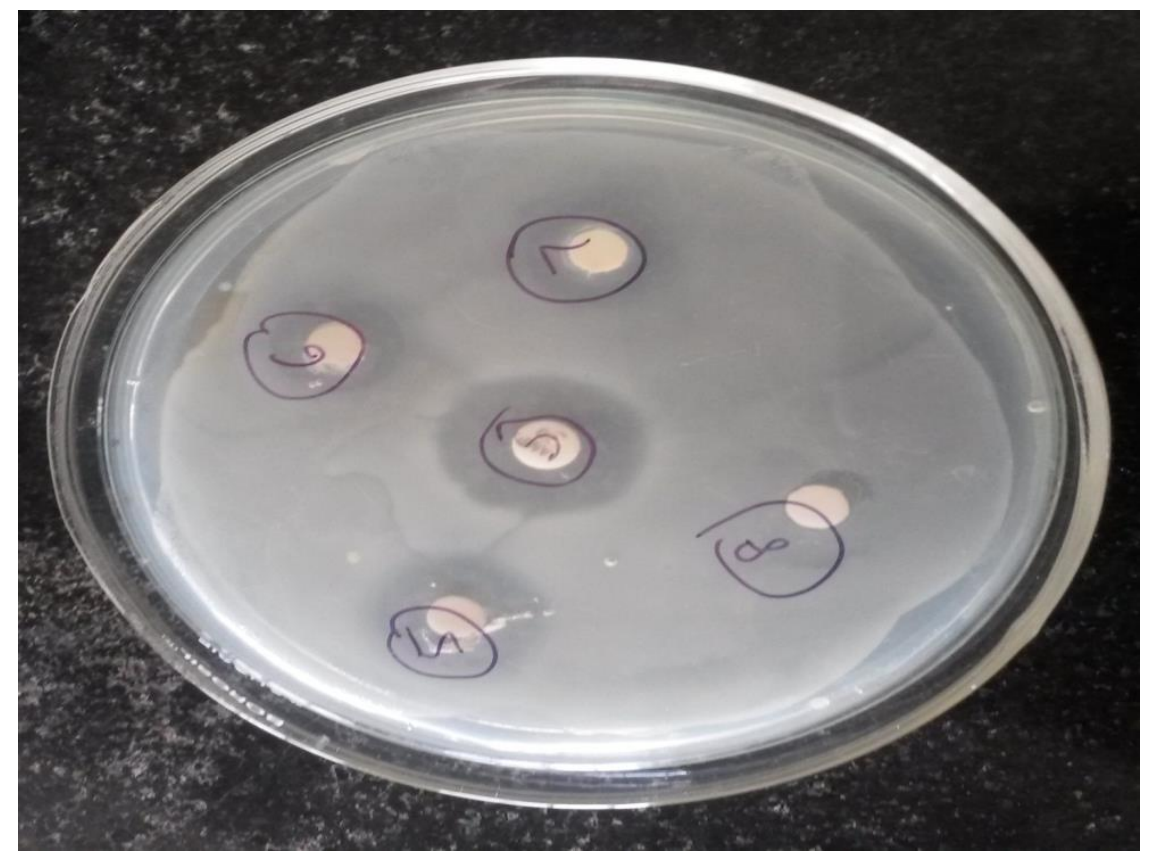


Fig 4.2.1c: Treatment 5:0.08g of copper/ml of titanium isopropoxide; Treatment 6:0.1g of copper/ml of titanium isopropoxide; Treatment 7: Titanium isopropoxide; Treatment 8: isopropanol; standard.

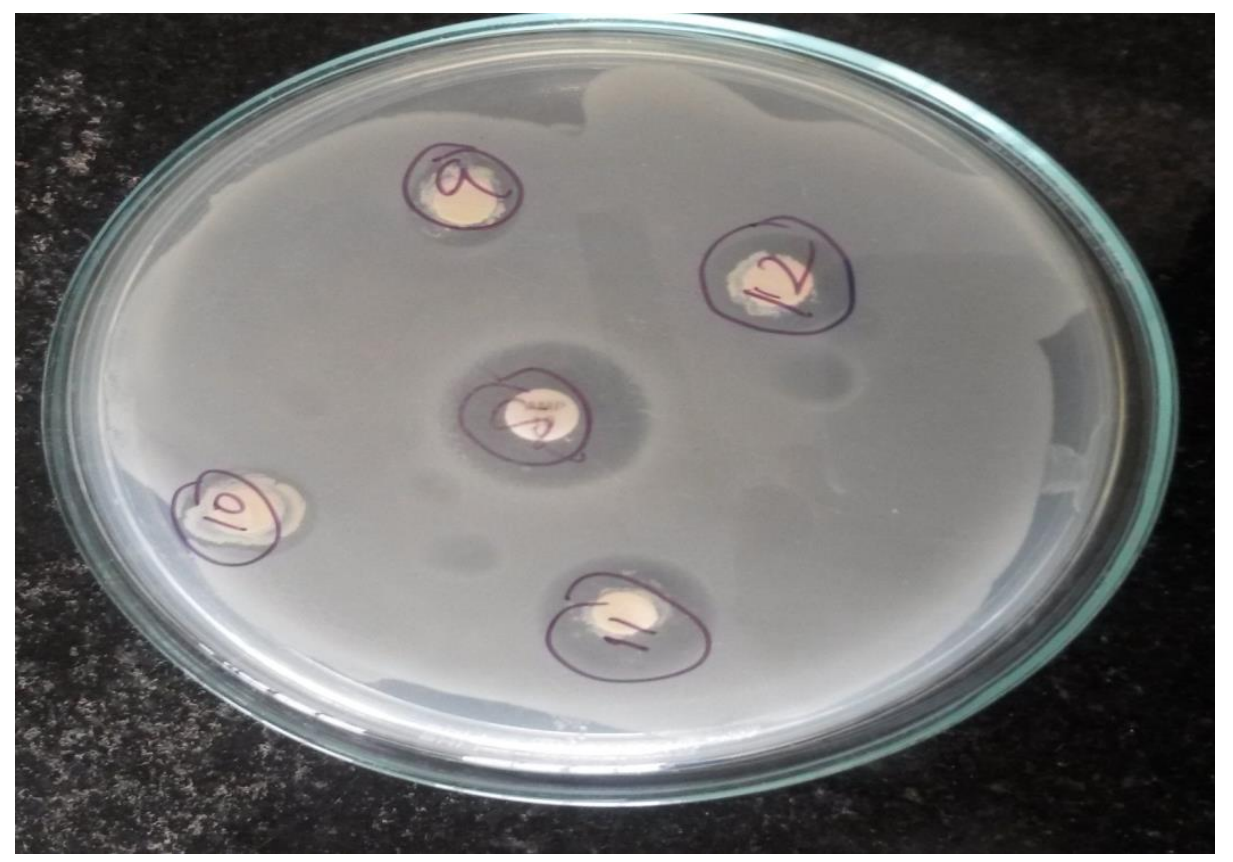

Fig 4.2.1d: Treatment 9:0.02g of zinc/ml of titanium isopropoxide; Treatment 10:0.04g of zinc/ml of titanium isopropoxide; Treatment 11:0.06g of zinc/ml of titanium isopropoxide; Treatment 12:0.08g of zinc/ml of titanium isopropoxide; standard. 


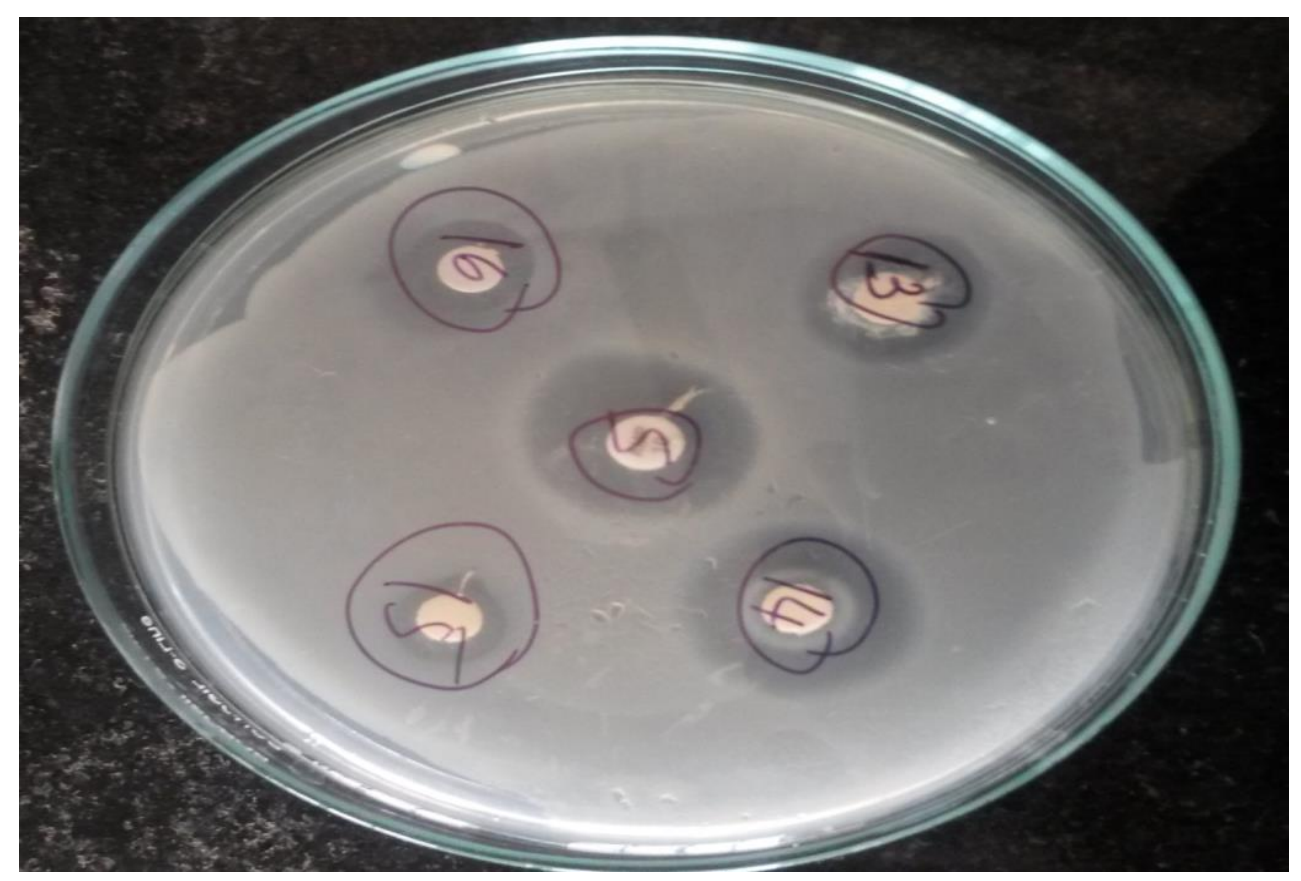

Fig 4.2.1e: Treatment 17:0.06g of copper/ml of titanium isopropoxide; Treatment 18:0.08g of copper /ml of titanium isopropoxide; Treatment 19:0.1g of copper/ml of titanium isopropoxide; Treatment 20:0.02g of zinc/ml of titanium isopropoxide; standard.

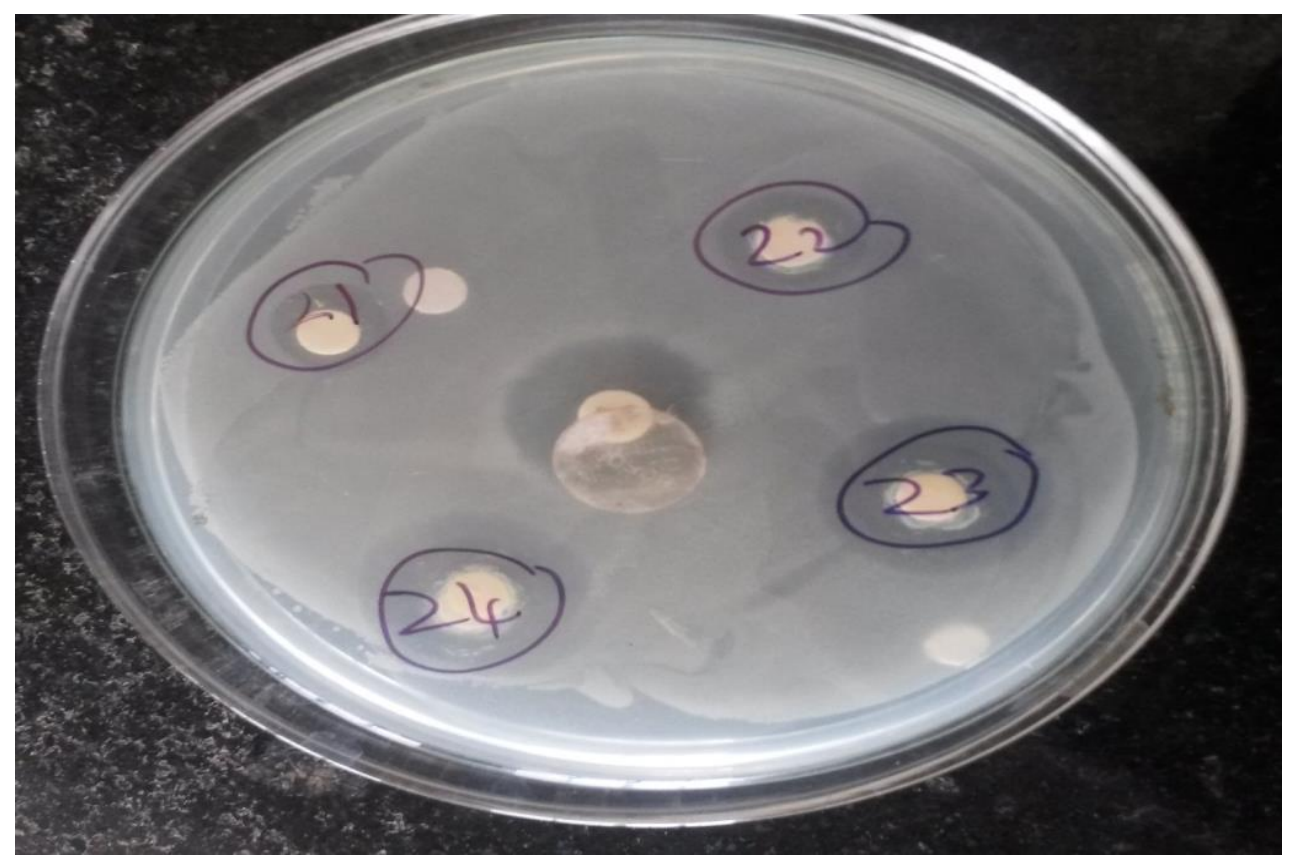


Fig 4.2.1f: Treatment 21:0.04g of zinc/ml of titanium isopropoxide; Treatment 22:0.06g of zinc/ml of titanium isopropoxide; Treatment 23:0.08g of zinc/ml of titanium isopropoxide; Treatment 24:0.1g of zinc/ml of titanium isopropoxide; standard.

Titanium isopropoxide showed inhibition of growth of E.coli which was accentuated by addition of zinc and copper as dopants. Isopropanol showed no zone of inhibition; This test is done in order to optimise concentration of dopant which was $10 \%$ in case of zinc and $8 \%$ in case of copper. Zinc at $10 \%$ was chosen for further testing as it showed better zone of inhibition than copper. This was studied in comparison with standard antibiotic disc here ampilicin was used.

4.2.2 Growth curve analysis: The effect of exposure of water to titanium isopropoxide with and without doping was studied using growth curve analysis. Figure 4.2.2 shows the growth curve with respect to time. The result clearly demonstrates the inhibition of growth of E.coli in all the treatments. It shows titanium isopropoxide doped with zinc thin films showed better inhibition when compared to titanium isopropoxide or titanium isopropoxide doped with copper . Inhibition can be easily distinguished with control where bacteria were allowed to grow in media.

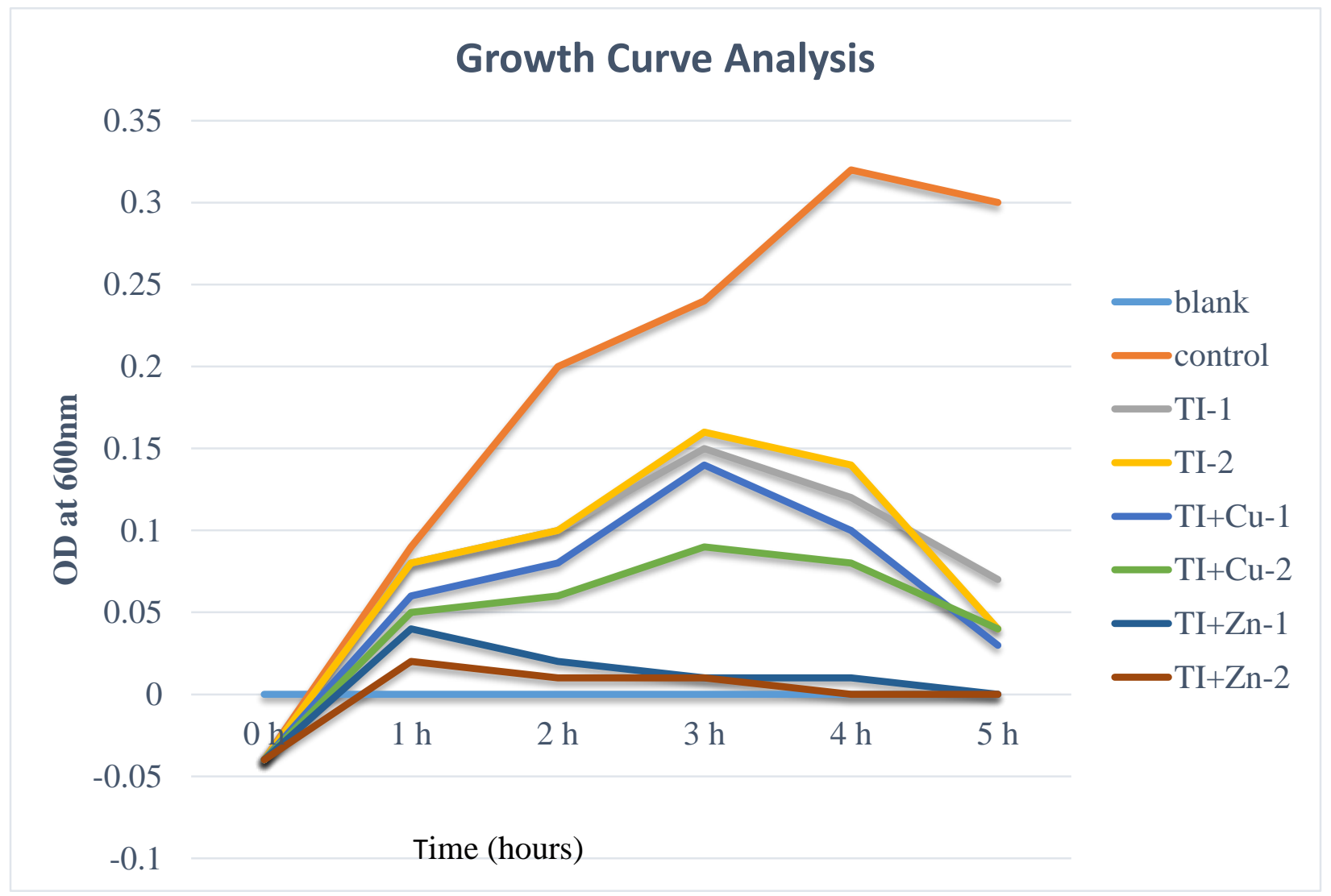


Fig 4.2.2.: Growth curve analysis of E.coli as affected by zinc and copper doped $\mathrm{TiO}_{2}$

This test was done to in order to know minimum time required for inhibition when compared to control that is $2 \mathrm{~h}$. Growth curve analysis of E.coli grown in broth in absence or presence of titanium isopropoxide with and without dopants showed that titanium isopropoxide reduced the bacterial growth. Addition of dopants increased the degree of inhibition. Zinc reduced bacterial growth in two hours when compared to copper and titanium isopropoxide which took longer time to inhibit. Control grew for some time and then curve began to drop which showed inhibition due to lack of nutrients Zinc is proven to be toxic to most of pathogens when compared to that of copper which inhibit only a few strains of bacteria.

4.2.3 Methylene blue: This is preliminary test done in order to know quality of milk and if it is fit for consumption or not. The effect of addition of doped $\mathrm{TiO}_{2}$ on methylene blue reduction test was carried out and the results showed that there is a disappearance of blue colour in $2 \mathrm{~h}$ for raw water (inoculated with E.coli culture ) while $\mathrm{TiO}_{2}$ treated water took $7 \mathrm{~h}$ to achieve same level of reduction (Fig 4.2.3).

Fig 4.2.3: Methylene blue reduction test of water: a) Methylene blue with E.coli and b) Methylene blue with E.coli and $\mathrm{TiO}_{2}$.
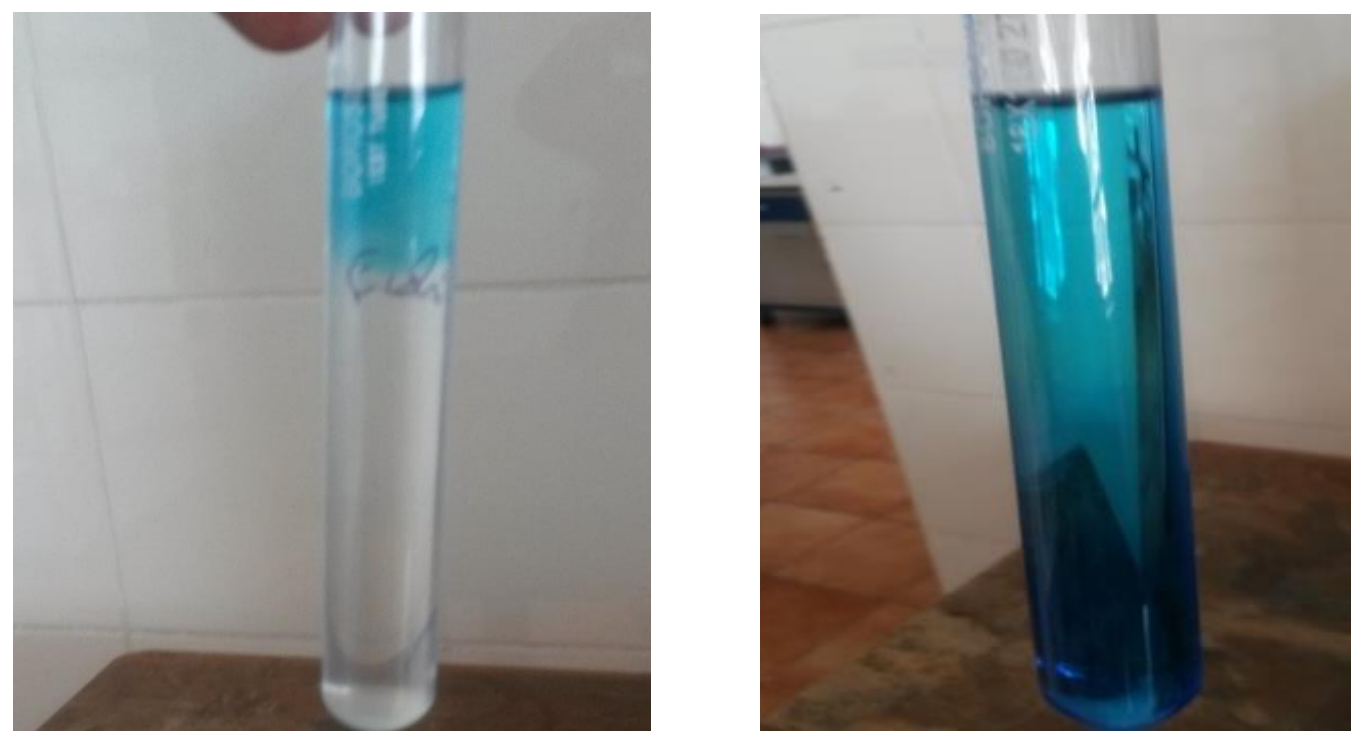

a) Methylene blue with E.coli
b) Methylene blue with E.coli and $\mathrm{TiO}_{2}$

Methylene blue with E.coli showed colour change from blue to colourless showing that E.coli activity reduces methylene blue within $2 \mathrm{~h}$. Blue colour reappears on the top interface due to reoxidation of methylene blue. Methylene blue with E.coli and $\mathrm{TiO}_{2}$ showed no colour change as there was inhibition of E.coli even after $24 \mathrm{~h}$. Water contaminated with culture could reduce methylene blue in $2 \mathrm{~h}$ suggesting high bacterial activity. Addition of zinc doped $\mathrm{TiO}_{2}$ increased the time of reduction to $7 \mathrm{~h}$ indicating loss of microbial number / activity. Addition of doped $\mathrm{TiO}_{2}$ alone to methylene blue without culture in beaker did not cause reduction supporting the idea that the reduction is not chemical but microbial in nature.

4.2.4 Serial dilution method: This test is used to determine number of colonies present in given sample. Thin film of $\mathrm{TiO}_{2}$ coated on $7.5 \mathrm{~cm}$ x $2.5 \mathrm{~cm}$ microscopic slide was dipped into $200 \mathrm{ml}$ water for $30 \mathrm{~min}$. Table 4.2.4 shows the results of microbial counts. It can be observed that nearly five $\log$ fold reduction in bacterial population has occurred within a short exposure time $(2 \mathrm{~h})$. The result of exposure to $\mathrm{TiO}_{2}$ thin film on bacterial numbers as estimated by serial dilution plate count is shown in table 4.2.4.

Table 4.2.4: Effect of $\mathrm{TiO}_{2}$ thin film on microbial population of tap water for 30 min measured by serial dilution plate count.

\begin{tabular}{llll}
\hline Time of exposure & Bacterial count & Rog (counts) & $\begin{array}{l}\text { Reduction } \\
(\%)\end{array}$ \\
to $\mathrm{TiO}_{2}(\mathbf{h})$ & $(\mathbf{C F U} / \mathrm{ml})$ & 7.9 & 0 \\
\hline 0 & $75^{*} 10^{6}$ & 3.4 & 99.9 \\
\hline
\end{tabular}

Fig 4.2.4: plate count a) $0 \mathrm{~h} \mathrm{b)} 2 \mathrm{~h}$ ) 

a) $0 \mathrm{~h}$

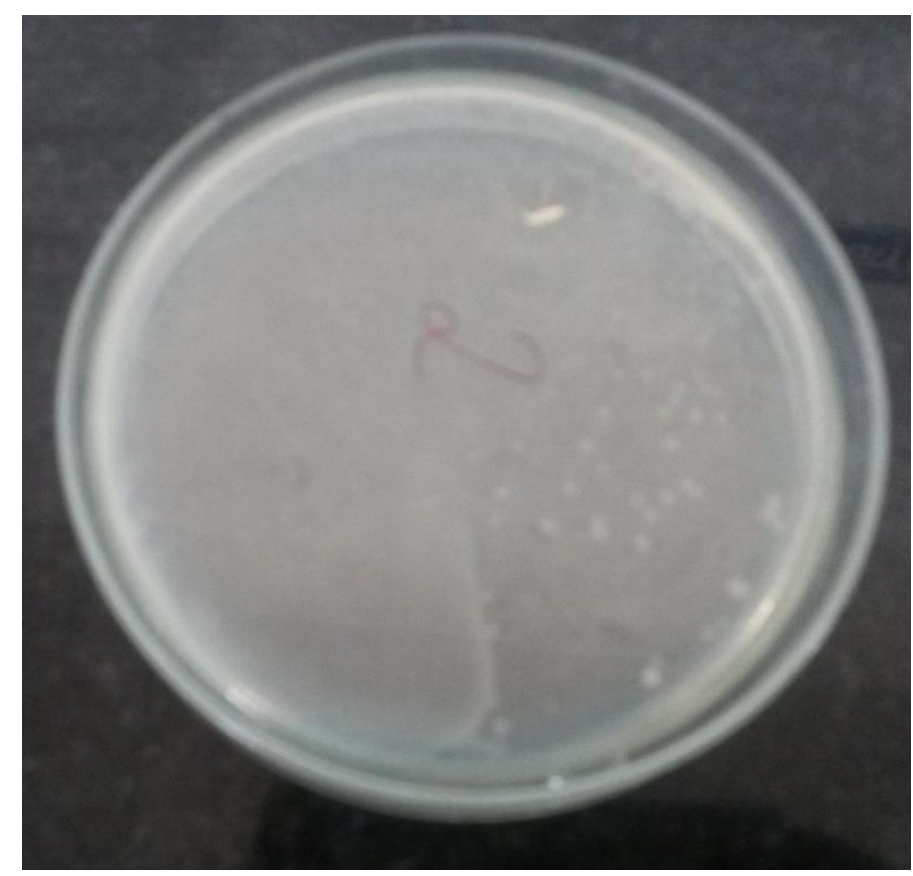

b) $2 \mathrm{~h}$

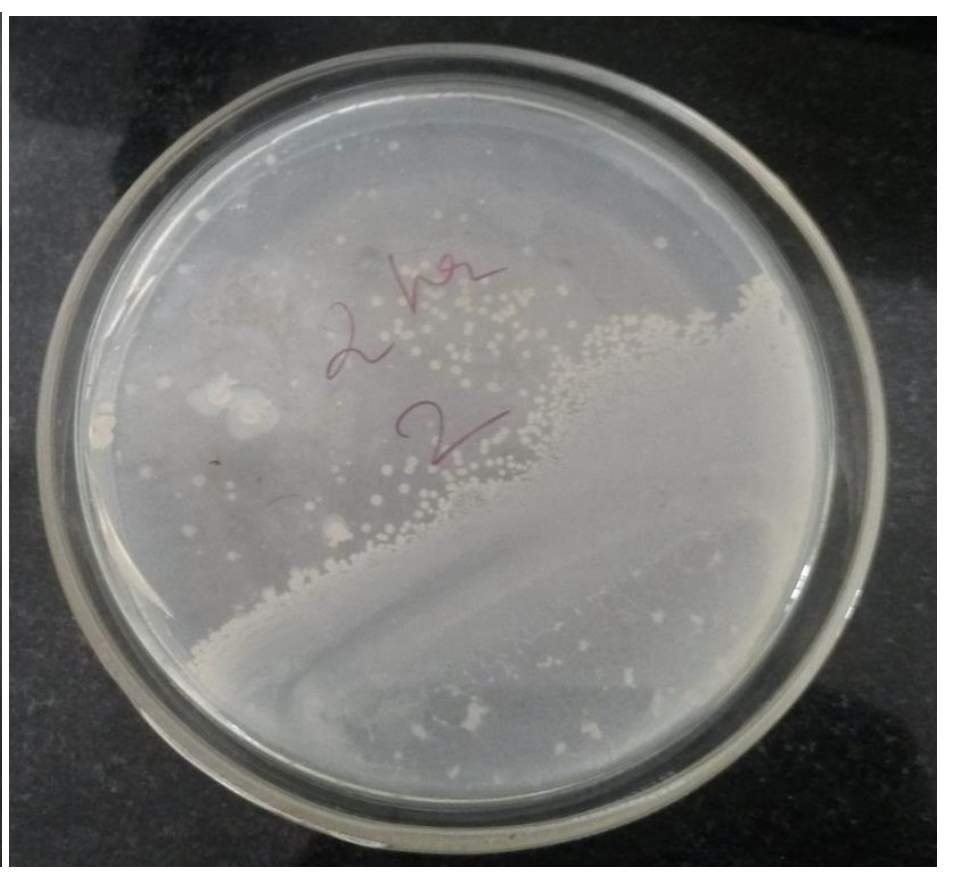

4.3 Effect of doped $\mathrm{TiO}_{2}$ thin films on microbial load of milk:

The effect of zinc and zinc with silver doped $\mathrm{TiO}_{2}$ thin films on the quality of milk was tested using clot on boiling, titrable acidity, methylene blue reduction and plate count. Consolidated results are shown in Table 4.3. Control milk curdled which was result of high titrable acidity value and also methylene blue reduced in $2 \mathrm{~h}$ attributed to microbial activity. Exposure of milk to zinc and zinc with silver doped $\mathrm{TiO}_{2}$ thin film showed low titrable acidity value which was insufficient to curdle milk and also methylene blue reduced in 4-8 $\mathrm{h}$ indicating loss of microbial activity. This is also supported by decrease in bacterial counts from 8 million at zero time to $2-2000$ in $2 \mathrm{~h}$. 

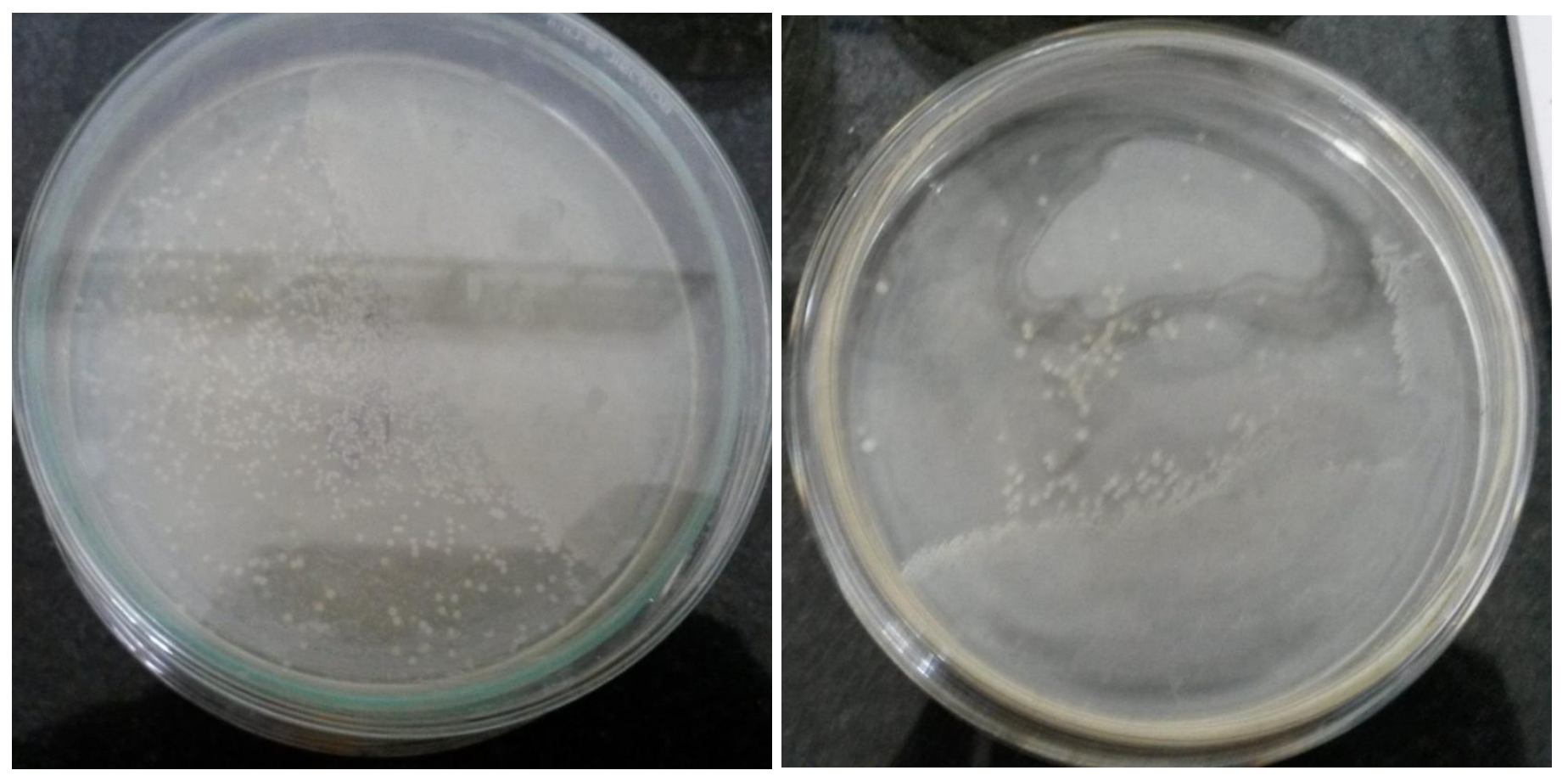

a) Control

b) zinc (2hr)

Fig 4.3.1: Colony count a) control b) zinc (2hr)

Table 4.3: Effect of zinc and zinc with silver doped $\mathrm{TiO}_{2}$ thin films on quality of milk.

\begin{tabular}{llllll}
\hline & Control & Zinc $(1 \mathrm{~h})$ & $\begin{array}{l}\text { Zinc with silver } \\
(1 \mathrm{~h})\end{array}$ & Zinc $(2 \mathrm{~h})$ & $\begin{array}{l}\text { Zinc with silver } \\
(2 \mathrm{~h})\end{array}$ \\
\hline COB & Curdling & No ppt & No ppt & No ppt & No ppt \\
$\begin{array}{l}\text { Acidity } \\
\text { (percentage) }\end{array}$ & 0.225 & 0.135 & 0.09 & 0.079 & 0.045 \\
MBR (h) & 2 & 6 & 8 & 7 & 4 \\
Count $(\mathrm{CFU} / \mathrm{ml})$ & $80,00,000$ & $3,50,000$ & 20 & 2,000 & 2 \\
\hline
\end{tabular}




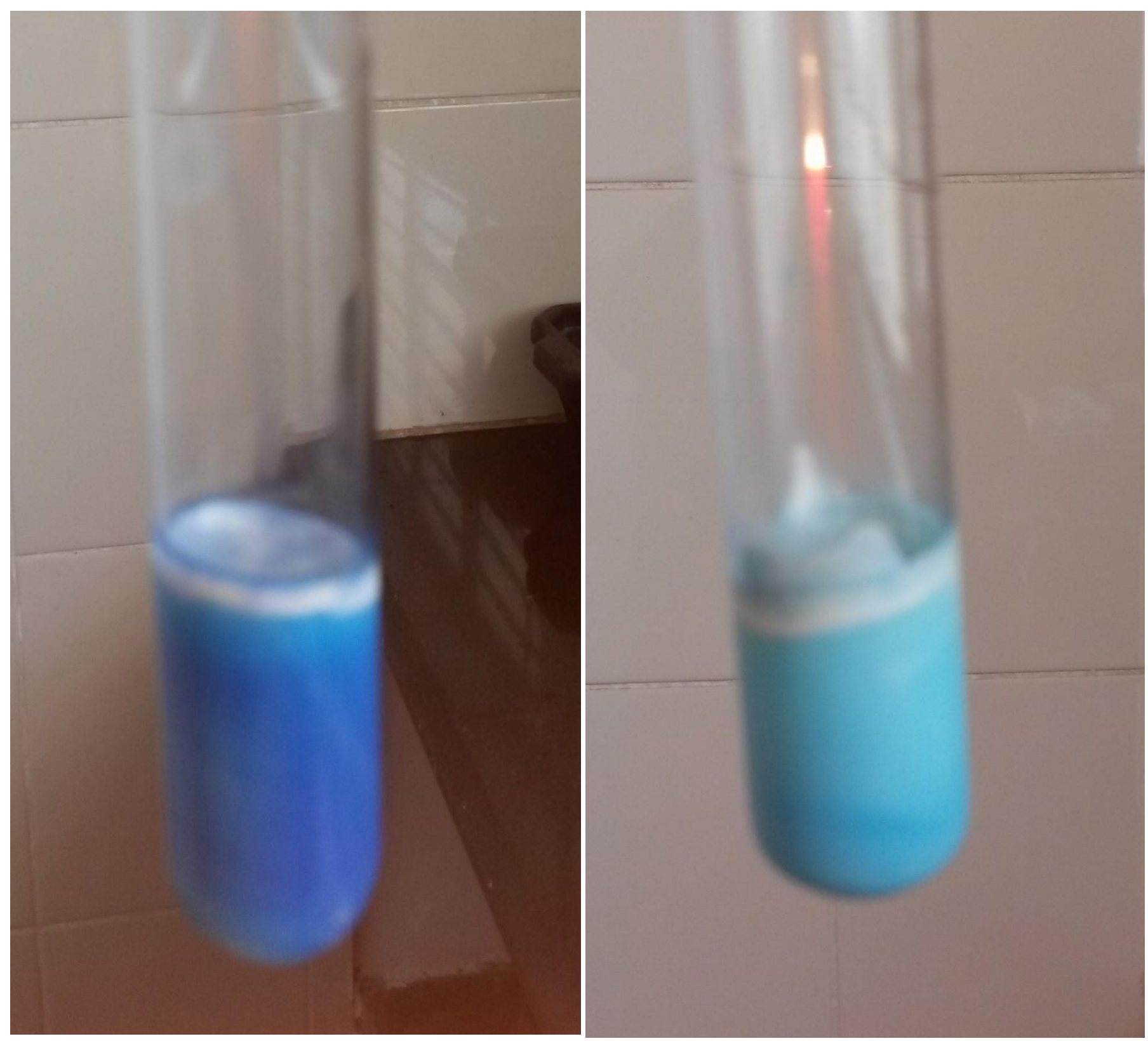

Fig 4.3.2: Methylene blue

The effect of doped $\mathrm{TiO}_{2}$ thin films on quality of milk was tested. Control milk reduced methylene blue in $2 \mathrm{~h}$ indicating high microbial load. Addition of doped $\mathrm{TiO}_{2}$ increased the time for reduction of methylene blue which indicated that there was a reduction in microbial number / activity.

Milk is a good medium for the growth of microorganism. A variety of microorganism can be found in both raw milk and pasteurized milk. These microbes reduce the oxidation reduction potential of the milk medium due to the exhausted oxygen by the microorganism. Milk is 
contaminated during the milking process, use of unsterilized dairy utensils such as milking machines, milk cans etc. Methylene blue reductase test is used to determine the quality of the milk. The principle of methylene blue reduction test is that the colour imparted to the milk by adding a dye like methylene blue will disappear more or less quickly, which depends on the quality of the milk sample to be examined. Methylene blue is a redox indicator that lose its colour under the absence of oxygen. The depletion of oxygen in the milk is due to the production of reducing substances in the milk due to increase in rate of bacterial metabolism. The dye reduction time refers to the microbial load in the milk and the total metabolic reactions of the microorganism. The presence of light fastens the reduction rate; hence the test tube under observation should be tightened properly.

Titrable acidity of milk has long been recognized and employed as an indicator of quality (Griffiths et al., 1988). It is expressed in terms of percentage lactic acid since lactic acid is the principal acid produced by fermentation after milk is drawn from the udder. Fresh milk, however, does not contain any appreciable amount of lactic acid and therefore an increase in acidity is a rough measure of its age and bacterial activity. Within a short time after milking, the acidity increases perceptibly due to bacterial activity. The degree of bacterial contamination and the temperature at which the milk is kept are the chief factors influencing acid formation. Therefore, the amount of acid depends on the cleanliness of production and the temperature at which milk is kept. For this reason, determination of acid in milk is an important factor in judging milk quality. Acidity affects taste as well. When it reaches about $0.3 \%$, the sour taste of milk becomes sensible. At $0.4 \%$ acidity, milk is clearly sour, and at $0.6 \%$ it precipitates at normal temperature. At acidity over $0.9 \%$, it moulds. Milk contains energy sources such as lactose (sugar), nitrogenous compounds such as proteins, amino acids, ammonia, urea etc. for the growth of microorganism.

Clot on boiling milk occurred after $2 \mathrm{~h}$ in control milk. While no such precipitation was observed in $\mathrm{TiO}_{2}$ treated milk. Control milk had highest titrable acidity while doped $\mathrm{TiO}_{2}$ treated samples showed variable amounts of acid; which is insufficient to curdle the milk. Bacterial population as measured by serial dilution plate count also decreased by five log folds with zinc doped $\mathrm{TiO}_{2}$ and while zinc with silver doped $\mathrm{TiO}_{2}$ showed drastic reduction to double digits. Silver is a known antibacterial substance and hence this result is not surprising. 


\subsection{Quality test in milk sample:}

Milk was treated with $\mathrm{TiO}_{2}$ thin films doped with zinc and were tested to check if these films had any effect on physico-chemical properties of milk sample (30).

\subsubsection{Detection of Cane Sugar by Modified Seliwanoff's method (qualitative method):}

Sucrose is absent in milk and its presence indicates adulteration. The acid hydrolysis of polysaccharides and oligosaccharides yields simpler sugars followed by furfural as by- product. The dehydrated ketose then reacts with the resorcinol to produce a deep cherry red colour. In case of aldoses, they react to produce a faint pink colour. When $\mathrm{TiO} 2$ treated milk sample was tested for sugar, there was no colour change indicating absence of sucrose. In pure milk sample no colour change is observed. (Reference: - IS 1479 (Part I) 1961 (Reaffirmed 2003) Methods of test for Dairy Industry - Rapid Examination of Milk. Bureau of Indian Standards, New Delhi).

\subsubsection{Test for presence of Hydrogen Peroxide}

Hydrogen Peroxide is used in preserving milk and also as a bleaching agent. Presence of hydrogen peroxide would increase $\mathrm{pH}$ and antibacterial activity. When treated sample was checked there was no colour change indicating absence of hydrogen peroxide (Reference: - A.O.A.C 17thedn, 2000 Official Method 957.08 Hydrogen Peroxide in milk).

\subsubsection{Detection of Cellulose in Milk}

Sample when treated with thin films showed no colour change indicating absence of cellulose (Reference: - Manual Methods of Analysis for Adulterants \& Contaminants in Foods. I.C.M.R 1990 page 27).

\subsubsection{Detection of Sodium Chloride in milk}

Absence of sodium chloride was observed by no change in colour in treated sample. (Reference: Pearson's Composition and Analysis of Foods, $9^{\text {th }}$ edn,1991 - Modified Mohr method, page 14).

\subsubsection{Detection of Starch}


Test for starch was found negative as there was no colour change in treated sample. (Reference: IS 1479 (Part I) 1961 (Reaffirmed 2003) Methods of test for Dairy Industry - Rapid Examination of Milk. Bureau of Indian Standards, New Delhi).

\subsection{6 $\mathrm{pH}$ of raw milk sample}

The control and sample were kept under ambient room temperature of $26.5^{\circ} \mathrm{C}$ for a period of 14 hours and $\mathrm{pH}$ of samples were measured at regular intervals. $\mathrm{pH}$ was found to be 6.61 which was within the specified range. $\mathrm{pH}$ indicate that solution was stable over period of time and thin films had no effect on its acidity.

\begin{tabular}{|l|l|l|}
\hline Time (min) & pH of Control Sample & pH of Treated Sample \\
\hline 0 & 6.61 & 6.61 \\
\hline 60 & 6.61 & 6.61 \\
\hline 200 & 6.61 & 6.61 \\
\hline 250 & 6.61 & 6.61 \\
\hline 300 & 6.61 & 6.61 \\
\hline 450 & 6.62 & 6.61 \\
\hline 600 & 6.52 & 6.61 \\
\hline 650 & 6.41 & 6.55 \\
\hline 700 & 6.40 & 6.52 \\
\hline 750 & 6.32 & 6.51 \\
\hline 800 & 6.31 & 6.50 \\
\hline 850 & 6.30 & 6.50 \\
\hline 900 & 6.30 & 6.50 \\
\hline 950 & 6.30 & 6.50 \\
\hline & & \\
\hline
\end{tabular}

\subsubsection{Total Solid Fat content}


Total Solid fat content of the sample was estimated to be $1.83 \%$

\subsubsection{Specific Gravity of Sample}

Weight of raw milk sample and treated milk sample was found to be same that is 1.0325 .

\section{CONCLUSION}

$\mathrm{TiO}_{2}$ thin films doped with zinc and copper were synthesized using sol-gel process and characterized using FTIR and SEM. FTIR showed the presence of $\mathrm{Zn}, \mathrm{Ag}$, and $\mathrm{TiO}_{2}$. While SEM showed a pore size of $0.5 \mu \mathrm{m}$ on the surface. Treatment of water with $\mathrm{TiO}_{2}$ thin films doped with zinc and copper increased the time required for methylene blue reduction, decreased the bacterial count by five log folds. Treatment of milk sample with $\mathrm{TiO}_{2}$ thin films doped with zinc and zinc with silver also increased the time required for methylene blue reduction. Treated milk didn't curdle when boiled and also acidity wasn't very high. The bacterial count had reduced to two digits. Tests for detection of cane sugar, hydrogen peroxide, starch, cellulose, sodium chloride showed no colour change indicating that $\mathrm{TiO}_{2}$ thin films don't affect quality of milk. pH of sample was stable over period of time that is 6.61. Lastly total solid fat content of the sample was estimated to be $1.83 \%$ and weight of raw milk sample and treated milk sample was found to be same that is 1.0325 .

These results show the potential of using $\mathrm{TiO}_{2}$ thin films in reducing the microbial load and extending shelf life of milk.

Further these experiments can be carried out with other combination of metals as either dopants or base metals and also profile of various species of microorganisms can be studied in detail. In detail toxicology analysis of milk can be done by using invitro studies. This experiment was done on lab scale using glass microslide but on large scale it becomes obsolete as coating needs to be done large surface area which could be costly. So options of coating on glass rod and dipping in milk can and leaving it in the can from the time milk is drawn till its processed is one of the options and other option could be coating entire inner surface of milking vessel with film material. Both has its set of problems, in first case it needs to be addressed whether any metal residue is left in milk and in second case it needs to be seen if coating is reactive with material of milking vessel or any residue is left in this case also. If parameters are fine, then it is safe for human consumption. 


\section{References}

1. Rhea Fernandes (2009), Microbiology Handbook Dairy Products, Leatherhead Food International Ltd, London.

2. Handbook of Milk Composition by Robert G. Jensen Academic Press, 1995.

3. Loralyn H. Ledenbach and Robert T. Marshall, 2009, Microbiological Spoilage of Dairy Products.

4. Department of Animal Husbandry, Dairying \& Fisheries, GOI, India. Annual report 2015.

5. NDDB-http://www.nddb.org/English/Genesis/Pages/Operation-Flood.aspx.

6. Brown K.L. (1991), Effects of heat resistance in food processing, Food Technology International Europe, 87-89.

7. Mackey B.M. \& Bratchell N. (1989), The heat resistance of Listeria monocytogenes, Letters in Applied Microbiology 9, 89-94.

8. Bradshaw J.G., Peeler J.T. \& Twedt R.M. (1991). Thermal resistance of Listeria spp. in milk. Journal of Food Protection 54, 12-14, 19.

9. Knabel S.J., Walker H.W., Hartman P.A. \& Mendonca A.F (1990), Effects of growth temperature and strictly anaerobic recovery on the survival of Listeria monocytogenes during pasteurization, Applied and Environmental Microbiology 56, 370-376.

10. Farber J.M., Daley E., Coates F., Emmons D.B. \& McKellar R (1992), Factors influencing survival of Listeria monocytogenes in milk in a high-temperature short-time pasteurizer. Journal of Food Protection 55, 946-951.

11. Linton R.H., Pierson M.D. \& Bishop, J.R. (1990), Increase in heat resistance of Listeria monocytogenes, Journal of Food Protection 53, 924-927.

12. Amigo L., \& Calvo, M.M. (1996), Addition of $\mathrm{CO}_{2}$ to raw milk to increase its useful life during refrigeration. Revista Espanolade Lechera 73, 25-27.

13. Joseph H. Hotchkiss, Brenda G. Werner, and Edmund Y.C. Lee. Addition of Carbon Dioxide to Dairy Products to Improve Quality: A Comprehensive Review, Comprehensive Reviews In Food Science And Food Safety-Vol. 5, 2006, 158-168.

14. Glass KA, Kaufman KM, Smith AL, Johnson EA, Chen JH, Hotchkiss J, Toxin production by Clostridium botulinum in pasteurized milk treated with carbon dioxide, Journal of food protection,1999, pp. 839-964, pp. 872-876 (5). 
15. Padmanaban Sivakumar, Pandian Sivakumar, Kamalakannan Anbarasu, Kannaiyan Pandian, and Sahadevan Renganathan, Synthesis of Silver Nanorods from Food Industrial Waste and Their Application in Improving the Keeping Quality of Milk, Industrial and Engineering Chemistry Research 2013, 52, 17676-17681.

16. Efrat Semo, Ellina Kesselman, Dganit Danino, Yoav D. Livney, Casein micelle as a natural nano-capsular vehicle for nutraceuticals, Food Hydrocolloids Volume 21, Issues 5-6, JulyAugust 2007, Pages 936-942, Food Colloids 2006.

17. J.F. Graveland-Bikker, C.G. de Kruif, Unique milk protein based nanotubes: Food and nanotechnology meet, Trends in Food Science \&Technology, Volume 17, Issue 5, May 2006, Pages 196-203.

18. Siti Hajar Othman ,Nurul Raudhah Abd Salam, Norhazlizam Zainal, Roseliza Kadir Basha, and Rosnita A. Talib, Antimicrobial Activity of $\mathrm{TiO}_{2}$ Nanoparticle-Coated Film for Potential Food Packaging Applications, Hindawi Publishing Corporation International Journal of Photoenergy, Volume 2014, Article ID 945930, 1-6.

19. A.R. West, 'Solid State Chemistry’ John willey \& Sons, Singapore, (2003).

20. K. L. Chopra, 'Thin Film Phenomena', McGraw Hill, New York (1969)

21. K. Sunada, T. Watanabe, K. Hashimoto, Studies on photokilling of bacteria on $\mathrm{TiO}_{2}$ thin film, Journal of Photochemistry Photobiology A: Chemistry 156 (2003) 227-233.

22. Hongbo Shi, Ruth Magaye, Vincent Castranova and Jinshun Zhao, Titanium dioxide nanoparticles: a review of current toxicological data, Particle and Fibre Toxicology 2013, 10-15.

23. Jinyuan Chen, Xia Dong, a Jing Zhaoa and Guping Tangb, In vivo acute toxicity of titanium dioxide nanoparticles to mice after intra peritioneal injection, Journal of Applied Toxicology 2009; 29: 330-337.

24. S. Dey, M. H Karim, Study on physicochemical and microbial quality of available raw, pasteurized and UHT milk during preservation, International Journal of Science Invention Today, 2013, 2(2), 150-157.

25. Kabui KK1, Arimi SM, Kang'ethe EK, Omore A, Makokha S , Nduhiu G, Mainga AO and Macharia JK, A Determination of Raw Milk Quality and the Most Suitable Microbiological Test at the Milk Collection Level in Two Regions of Kenya, International Journal of Veterinary Science, 4 (2): 55-59. 
26. M.Baby Jenitta, J. Sherly, K. Mohan, Studies on Microbial Quantity and Dissolved Oxygen Content of Raw Chilled Milk Samples Based On Methylene Blue Reduction Test and Oxidation Reduction Potential, International Journal of Engineering and Technical Research, Volume-2, Issue-9, September 2014.

27. Ya-Nan Chang, YaNan Chang, Mingyi Zhang, Lin Xia, Jun Zhang and Gengmei Xing The Toxic Effects and Mechanisms of $\mathrm{CuO}$ and $\mathrm{ZnO}$ Nanoparticles, Materials20

28. Isrihetty Senain, Nafarizal Nayan, Hashim Saim, Structural and Electrical Properties of $\mathrm{TiO}_{2}$ Thin Film Derived from Sol-gel Method using Titanium (IV) Butoxide,2010, International Journal of Integrated Engineering (Issue on Electrical and Electronic Engineering),29-35.

29. Ravishankar Rai V and Jamuna Bai A, Nanoparticles and their potential application as antimicrobials, www.formatex.info/microbiology3/book/197-209.

30. http://www.fssai.gov.in/Portals/0/Pdf/Draft_Manuals/MILK_AND_MILK_PRODUCTS.p df. 